\title{
Lawsonite-bearing eclogite from a tectonic mélange in the Ligurian Alps: new constraints for the subduction plate-interface evolution
}

\author{
MARCO SCARSI*, CRISTINA MALATESTA \& SILVIA FORNASARO \\ DISTAV, University of Genova, Genova, Italy
}

(Received 11 October 2016; accepted 3 April 2017; first published online 23 May 2017)

\begin{abstract}
Lawsonite eclogites are rare rocks and have been described from only a few localities in the world. Lawsonite-bearing assemblages are highly unstable and physico-chemical processes linked to exhumation may destroy them; only aggregates interpreted as pseudomorphs after lawsonite could be often recognized. In this paper, we present a detailed structural and petrological study of an area in the northwestern sector of the metaophiolitic high-pressure Voltri Massif (Ligurian Western Alps, Italy). The study area is characterized by a lawsonite-bearing eclogitic metagabbro associated with carbonated serpentinites and glaucophanic metasediments. The metagabbro body reached eclogitic metamorphic peak conditions at $T=465-477^{\circ} \mathrm{C}$ and $P=20.9-24.4$ kbar, with $\mathrm{H}_{2} \mathrm{O}$ continuously supplied to the system. $\mathrm{H}_{2} \mathrm{O}$ under-saturated conditions, with the occurrence of both lawsonite and epidote, characterized the exhumation path. Both the low temperature recorded by the body and the occurrence of variously carbonated serpentinites led us to interpret this area as a portion of the top of the subducted slab, coupled with a 'cool' mantle wedge, where both aqueous fluids and carbonaterich fluids were present. The occurrence of rocks belonging to different paleogeographic domains (e.g. continent versus ocean) and the multiple deformations recorded by the metagabbro suggest that this area was nearby the slab-mantle interface. This sector was thus affected by a shear regime that acted in a low-viscosity serpentinite channel, bringing these high-pressure rocks back to the surface.
\end{abstract}

Keywords: lawsonite-bearing eclogite, subduction plate interface, low-viscosity serpentinite channel, Ligurian Western Alps, Voltri Massif

\section{Introduction}

Lawsonite blueschists and eclogites are expected to be the prevailing lithotypes developing during deep subduction of the oceanic crust and should therefore be quite abundant in exhumed subduction complexes (Ravna et al. 2010). Thermal and chemical models predict that lawsonite should be widespread in subducted oceanic crust at pressure higher than 1.5 GPa (Zack et al. 2004). Nevertheless, lawsonite-bearing eclogites have been described from only a few localities in the world (e.g. McBirney, Aoki \& Bass, 1967; Watson \& Morton, 1969; Krogh, 1982; Caron \& Péquignot, 1986; Lardeaux et al. 1986; Oh, Liou \& Maruyama, 1991; Ghent, Stout \& Erdmer, 1993; Shibakusa \& Maekawa, 1997; Parkinson et al. 1998; Carswell et al. 2003; Och et al. 2003; Usui et al. 2003; Altherr et al. 2004; Harlow et al. 2004; Mattinson et al. 2004; Tsujimori, Liou \& Coleman, 2005; Tsujimori et al. 2006 $a, b$; Davis \& Whitney, 2006; Usui, Nakamura \& Helmstaed, 2006; Zhang \& Meng, 2006; Zhang, Meng \& Wan, 2007; Ghent, Tinkhan \& Marr, 2009; Ravna et al. 2010; Tsujimori \& Ernst, 2014; Vitale Brovarone \& Beyssac, 2014). When formed, lawsonite-bearing assemblages are observed to be highly unstable and

\footnotetext{
*Author for correspondence: marco.scarsi@edu.unige.it
}

their preservation requires to be accompained by substantial cooling and a rapid uplift (Compagnoni \& Maffeo, 1973; Carswell, 1990; Poli \& Schmidt, 1995; Maruyama et al. 1997; Okamoto \& Maruyama, 1999; Forneris \& Holloway, 2004; Zack et al. 2004; Zhang \& Meng, 2006; Brun \& Faccenna, 2008; Agard et al. 2009; Ravna et al. 2010; López-Carmona et al. 2011; Zucali \& Spalla, 2011). Overprinting by heating and fluid infiltration can destroy mineral assemblages typical of blueschist- and eclogite-facies conditions; as a result these assemblages are rare, and those preserving lawsonite-bearing eclogites are the rarest of all (Davis \& Whitney, 2006).

In this paper we present the structural and petrological study of a lawsonite-bearing eclogitic metagabbro, cropping out in the north-western sector of the metaophiolitic Voltri Massif (Ligurian Western Alps, Italy).

The main metagabbro body is a $20 \mathrm{~m}$ sized lens, in contact with Na-amphibole-bearing metasediments; both are interlayered with serpentinite schists. The area is characterized also by the occurrence of ophicalcites and serpentinites with a variable degree of carbonation, up to their complete transformation into listvenites. The latter are the result of hydrothermal metasomatic processes related to intense $\mathrm{CO}_{2}$-rich fluid circulation (Hansen et al. 2005). 
In the last few years both the occurrence of highpressure C-bearing lithologies and the mechanisms of interaction of $\mathrm{CO}_{2}$-rich fluids with rocks have been extensively examined to evaluate the carbon fluxes in subduction zones and the turnover rate of $\mathrm{CO}_{2}$ to the atmosphere (e.g. Kerrick \& Connolly, 1998; Ague \& Nicolescu, 2014; Kelemen \& Manning, 2015).

The aim of this paper is dual: (i) to study the structural and petrological features of the lawsonite-bearing eclogitic metagabbro, to infer its $P-T$-Deformation history, and (ii) to derive further information on the tectono-metamorphic history of the area, i.e. to understand the tectonic evolution at a subduction plate interface (Cannaò et al. 2016).

\section{Geological background}

The Voltri Massif is located at the southernmost termination of the Western Alps (Fig. 1a) and it is made up of metaophiolitic rocks associated with metasediments and slices of subcontinental lithospheric mantle. These rocks underwent a complex Alpine tectonometamorphic evolution, with blueschist- to eclogitefacies peak metamorphism with variable retrogressive overprints (Chiesa et al. 1975; Capponi, 1987, 1991; Capponi et al. 1994; L. Crispini, unpub. Ph.D. thesis, Univ. degli Studi di Genova, 1996; Capponi \& Crispini, 2002, 2008b).

The Voltri Massif metaophiolites largely consist of serpentinites with metagabbros and lenses of metabasite; metasediments represent the cover of the ophiolitic basement and encompass the whole range from quartzschist to calcschist and micaschist, and are locally associated with metabasites (Chiesa et al. 1975; Cortesogno \& Forcella, 1978). In the study area, slices of continent-derived metasediment (i.e. quartzites and marbles) and subcontinental mantle (i.e. lherzolites, harzburgites with minor pyroxenites and dunite bodies) occur. Outcrops of upper Eocene - lower Miocene sedimentary deposits of the Tertiary Piedmontese Basin (TPB) cover the Voltri Massif rocks in nonconformity.

In general, the main lithologies of the Voltri Massif show several superposed structures, achieved under different tectonic conditions and ranging from ductile to brittle regime (Capponi \& Crispini, 2002). The oldest structures are eclogite/blueschist-facies foliation and rootless hinges of isoclinal folds that lack continuity across outcrops; they are related to subduction events. Later $D_{1} / D_{2}$ similar folds form under $\mathrm{Na}$-amphibole greenschist to greenschist sensu stricto metamorphic conditions; overprinting of $\mathrm{D}_{2}$ on the $D_{1}$ folds caused type 3 and rarely type 2 (Ramsay \& Huber, 1987) interference patterns. The $D_{1}$ and $D_{2}$ schistosity produce a composite fabric $(\mathrm{CF})$, which is the most evident surface on the field and controls the contacts between different lithologies.

Ductile structures recording extension parallel to the foliation (i.e. shear bands, boudins, foliation boudinage and extensional veins; Capponi \& Crispini, 1997) developed under greenschist-facies conditions.
A detailed description of the main structural features and evolution of the Voltri Massif can be found in Capponi (1987, 1991), Capponi et al. (1994), L. Crispini (unpub. Ph.D. thesis, Univ. degli Studi di Genova, 1996) and Capponi \& Crispini (2002, 2008b).

\section{Geology of the studied area}

The study area is located along the Roboaro River (GPS coordinates $\mathrm{N} 44.544686^{\circ}, \mathrm{E} 8.436038^{\circ}$ ), near Sassello village. This area is part of the metaophiolitic Voltri Massif and is characterized by the occurrence of rocks with different paleogeographic origins (oceanic versus continental). The main lithologies are, in decreasing order of areal extent, serpentinite, metagabbro, metabasite lenses ( 15 to $20 \mathrm{~m}$ wide) and ophicarbonate (Fig. 1b), derived from the ancient ocean-floor of the Ligurian Tethys; restricted outcrops of both ocean- (i.e. glaucophane-bearing calcschists) and continent-derived metasediments (i.e. dolostone) are present in the area; TPB sedimentary deposits widely occur.

We focused on an eclogitic metagabbro lens wrapped by serpentinites and glaucophanic metasediments. The serpentinites are antigorite-bearing with a mylonitic texture characterized by a pervasive foliation that dips NE-NW (Fig. 1b). They are affected by a variable degree of carbonation, propagating in mesh fractures (Fig. 2a) or in fractures parallel to the schistosity; locally serpentinites are completely transformed into listvenite.

The glaucophane-bearing metasediments are commonly associated with the metagabbro lenses (Fig. 2b); they include syn-kinematic stable calcite + dolomite + white mica + chlorite $+\mathrm{Na}$-amphibole + titanite (replacing rutile) + quartz + opaque minerals (e.g. pyrite) and rare apatite; relict intrafoliar folds develop a pervasive axial plane schistosity moderately dipping to the NE-NW (Fig. 3).

The main schistosity in both the serpentinite and metasediment is a composite foliation, related to the superposition of synmetamorphic deformational events.

The metagabbro lens shows a peculiar alternation of $\mathrm{Na}$-amphibole-rich blue layers and $\mathrm{Ca}-\mathrm{Na}$-pyroxenerich green layers, with a mylonitic texture (Fig. 4). Both layers include isoclinal intrafoliar folds $\left(D_{1}\right)$ that are the oldest recognizable event. $\mathrm{D}_{1}$ folds develop a pervasive Na-amphibole-bearing axial plane schistosity. The metagabbro was affected by a following folding event $\left(D_{2}\right)$, testified to by isoclinal folds (Figs $2 c$, 3 ), deforming all the previous structures and causing the alternation of the green and blue bands; the superposition of $D_{1}$ and $D_{2}$ structures produced a composite fabric dipping NE-NW, which shows the same attitude of the surrounding serpentinite and metasediment schistosity. Extension of fold limbs caused a millimetre- to centimetre-scale dominant symmetric boudinage of the 'rigid' $\mathrm{Ca}-\mathrm{Na}$-pyroxene-rich green layers (Figs 2d, 4) and the development of low-angle 

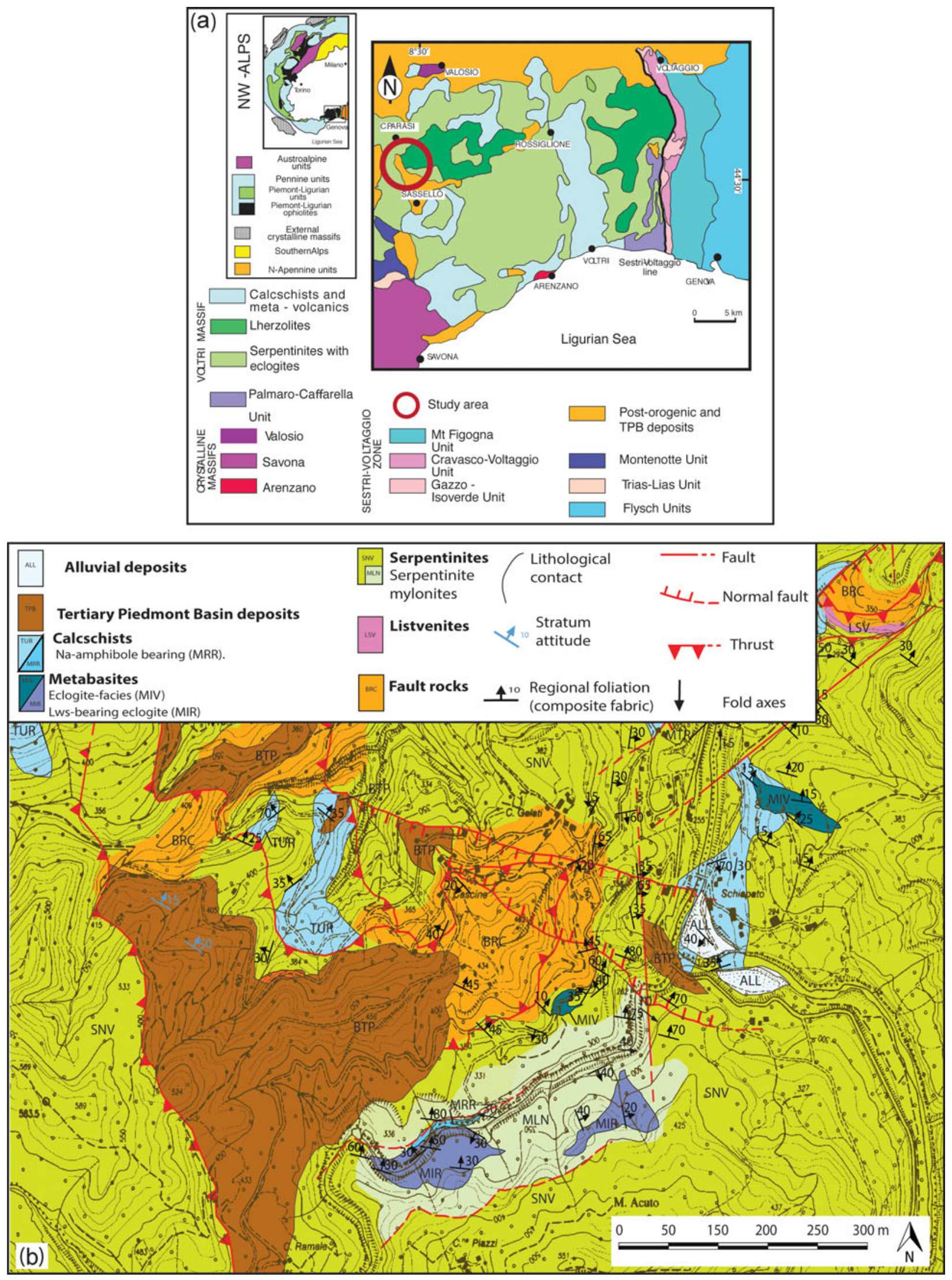

Figure 1. (Colour online) (a) Structural sketch map of the eastern Ligurian Alps and adjoining units; in the top left inset a structural sketch map of the Western Alps is shown. (b) Geological map of the studied area surrounding the Roboaro River. 

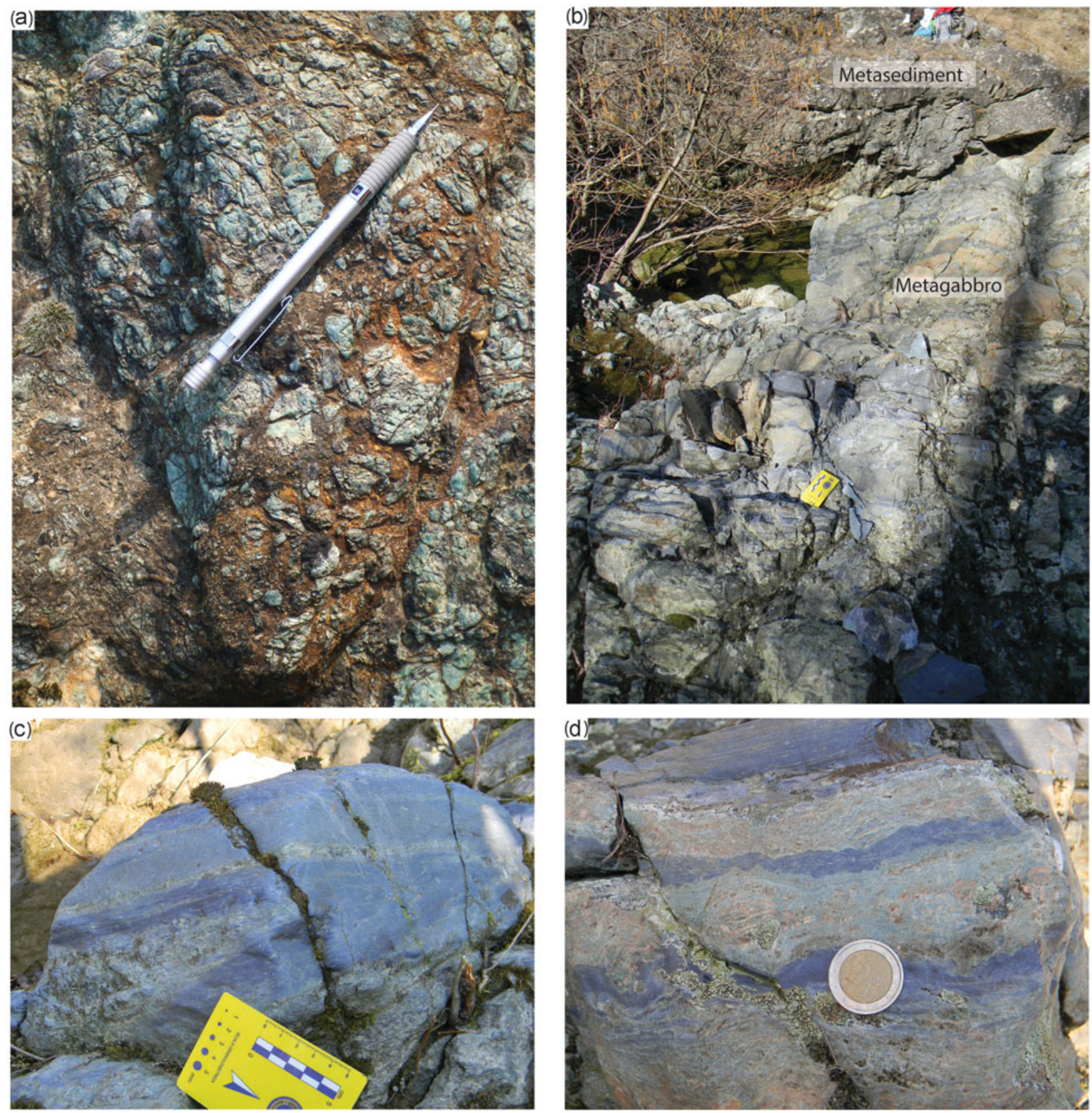

Figure 2. (Colour online) (a) Brecciated and carbonated serpentinites. (b) Overview of the metagabbro body and the glaucophanic metasediment lens. (c) Isoclinal fold $\left(\mathrm{D}_{2}\right)$ inside the metagabbro body deforming a Na-amphibole-rich blue layer. (d) Detail of the layering in the metagabbro body and boudinage of the $\mathrm{Ca}-\mathrm{Na}$-pyroxene-rich green layer. Pen for scale is $15 \mathrm{~cm}$ long; coin is $2.5 \mathrm{~cm}$ diameter.

shearing surfaces, defining an asymmetric boudinage, in the 'soft' Na-amphibole-rich blue layers. Indeed, the centimetre-thick $\mathrm{Ca}-\mathrm{Na}$-pyroxene-rich layers show prevailing straight to locally oblique necks, in which albite + titanite + Fe-oxide grow along the direction of maximum extension.

The TPB outcrops are at the top of the metaophiolitic sequence and show a sub-horizontal bedding.

The study area is also characterized by two main fault-systems: one is represented by high-angle to subvertical normal faults, whereas the other system is represented by a low-angle thrust fault, with splays isolating sigmoidal bodies.

\section{Petrography of the lawsonite-bearing eclogitic metagabbro}

The alternating green and blue layers, defining the composite fabric of the metagabbro body, are $\mathrm{Ca}-\mathrm{Na}-$ pyroxene and $\mathrm{Na}$-amphibole-rich respectively.

The green layers include millimetre- to centimetresized porphyroclasts of magmatic Ca-pyroxene (augite) that hosts sulphurs and that are partially to totally replaced by coronitic $\mathrm{Ca}-\mathrm{Na}-$ pyroxene $(1$; omphacite composition; Fig. 5a, b); fringes of Na-amphibole + pyrite or titanite grow from $\mathrm{Ca}-\mathrm{Na}$-pyroxene crystals (1), gradually replacing them (Fig. 5b-f). Ca-Na-pyroxene (2) 


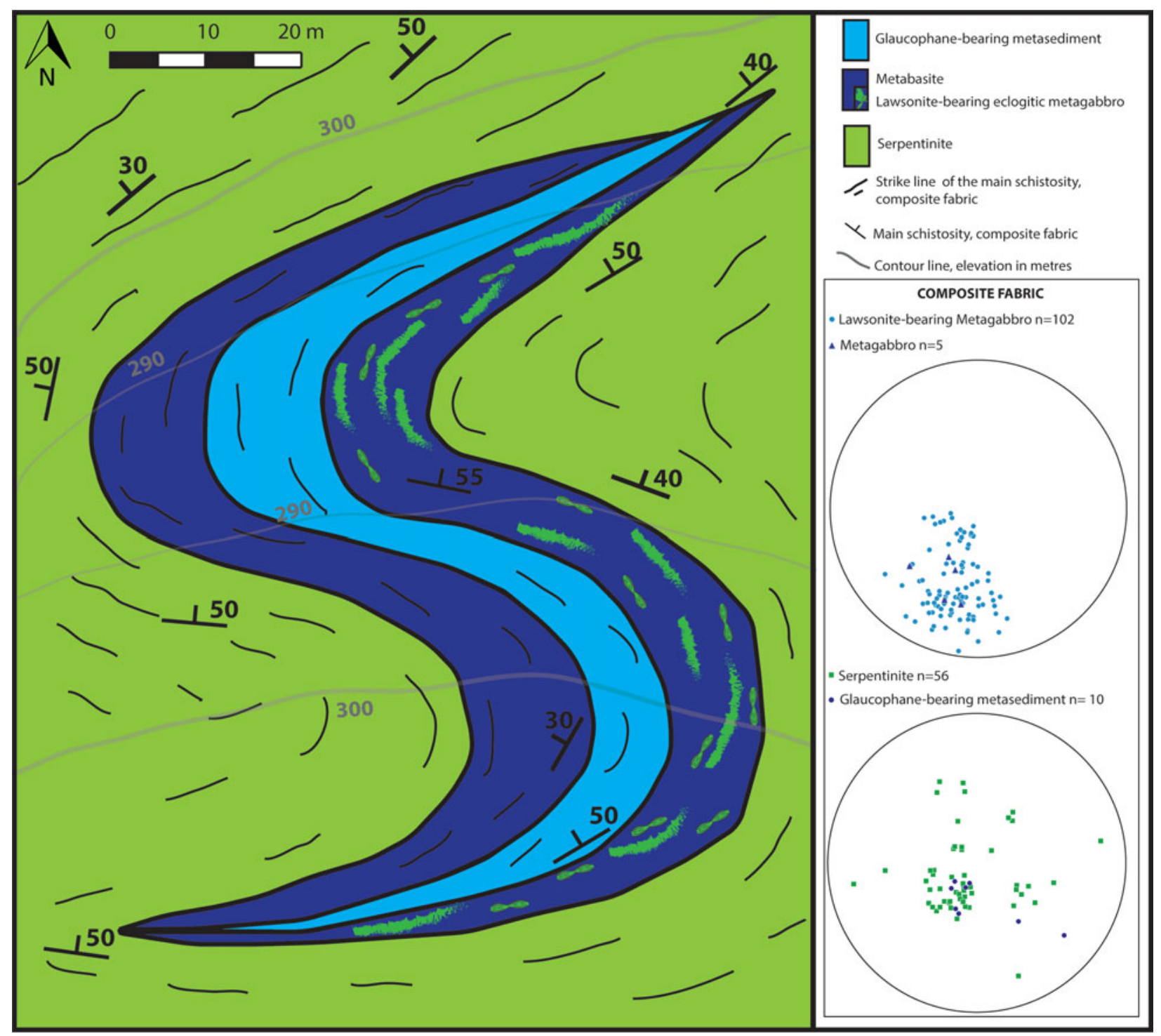

Figure 3. (Colour online) Geological map of the Roboaro River area; the Schmidt nets (lower hemisphere) show the attitude of the composite fabric in different lithotypes.

recrystallizes as syn-kinematic subgrains (Fig. 5a, c, d, e). Rare garnet includes fine-grained Na-amphibole (1) in the core (Fig. 6a) and grows in equilibrium with $\mathrm{Ca}-\mathrm{Na}$-pyroxene. Lawsonite nucleates in the Na-amphibole (2) pressure shadows growing from $\mathrm{Ca}-\mathrm{Na}$-pyroxene (1) and is replaced by later albite (Figs 5f, 6b).

The $\mathrm{Ca}-\mathrm{Na}$-pyroxene layers are overgrown by light-green syn-kinematic fine-grained clinozoisite + minor Na-amphibole (2-3) and white mica (phengite) (Fig. 5d, e). The clinozoisite-rich layers preserve rare garnet that is overgrown by Fe-epidote, glaucophane and chlorite (Fig. 6a).

The blue layers consist of syn-kinematic Naamphibole (2-3) + minor epidote, white mica (phengite), titanite and Fe-oxide. These layers include porphyroclasts, interpreted as former pyroxene (augite), replaced by fine-grained Na-amphibole (2-3) + clinozoisite $+\mathrm{Fe}$-oxide or showing fringes of $\mathrm{Na}$ - amphibole (2) + white mica and Fe-oxide. Locally relict pyrite, replaced by chalcopyrite, occurs.

Rare layers of fine-grained syn-kinematic titanite, including Fe-oxide and rutile, are preserved.

One main metamorphic peak event, resulting in two assemblages controlled by rock compositional layering, is therefore recorded by the rock $(1,2 ;$ Fig. 7$)$ : (i) the first assemblage is defined by the static crystallization of Ca-Na-pyroxene (1) + garnet (1) + rutile (1) \pm white mica (1) \pm Na-amphibole (1) \pm lawsonite; (ii) the second one consists of syn-kinematic $\mathrm{Ca}-\mathrm{Na}-$ pyroxene (2) + garnet (2) + Na-amphibole (2) + rutile (2) + white mica (2) + lawsonite.

These assemblages are replaced by retrograde synkinematic Na-amphibole (3) + epidote + white mica (3) + lawsonite + titanite.

The later crystallization event is marked by chlorite, albite and Ca-amphibole growing at the expense of garnet, $\mathrm{Ca}-\mathrm{Na}$-pyroxene and $\mathrm{Na}$-amphibole. 


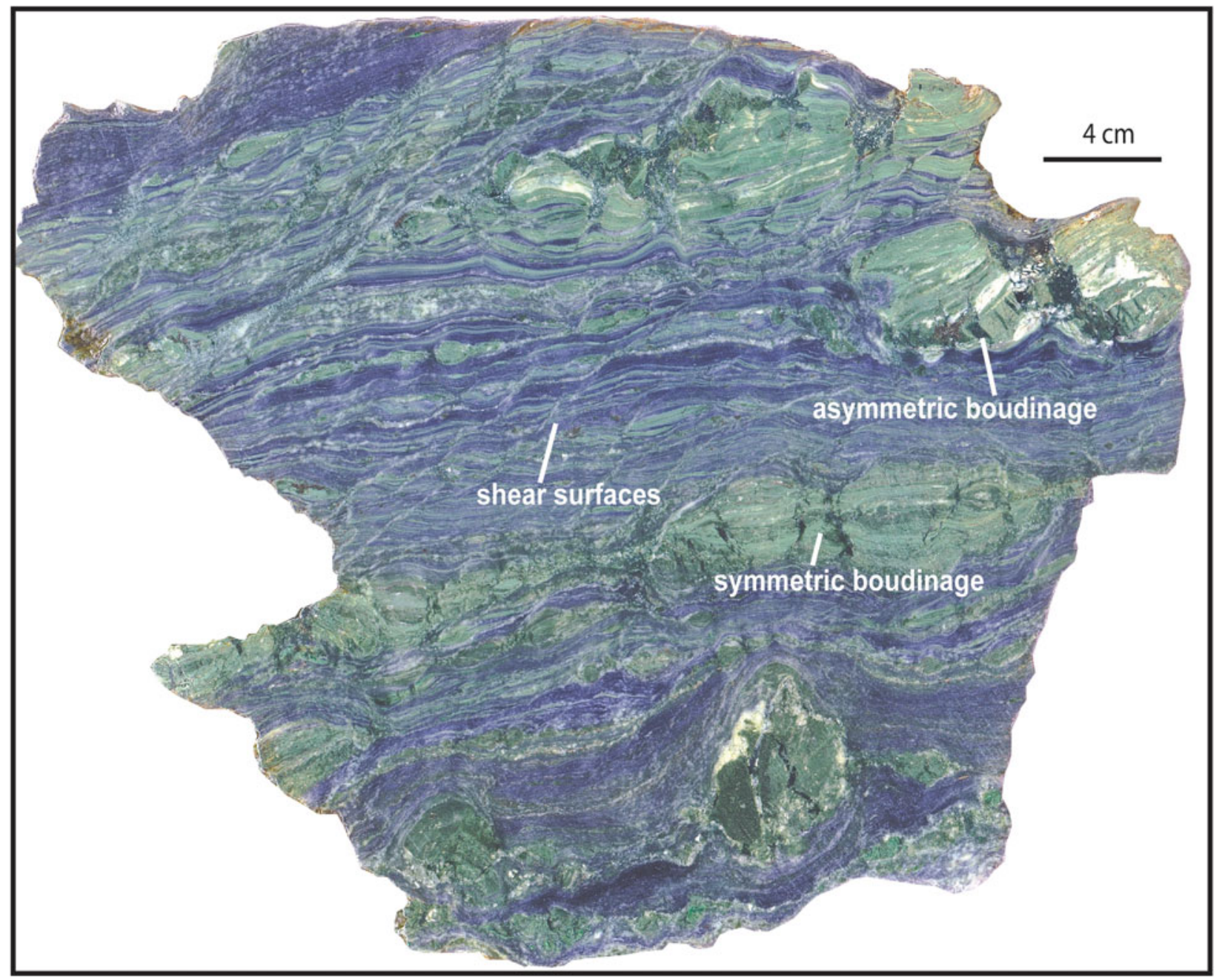

Figure 4. (Colour online) High-resolution scan of a sample from the metagabbro body, showing the peculiar green and blue layering; boudinage of the $\mathrm{Ca}-\mathrm{Na}$-pyroxene green layers and low-angle shearing surfaces in Na-amphibole-rich blue layers are visible.

\section{Mineral chemistry}

We analysed the chemical compositions of the main minerals from the lawsonite-bearing eclogitic metagabbro with an Electron Microprobe (JEOL 8200 Super Probe) at 'Ardito Desio' Earth Sciences Department (University of Milan, Italy), using a WDS system. The working conditions were set at $15 \mathrm{kV}$ accelerating voltage and $4.9 \mathrm{nA}$ beam current. Natural minerals were used as standards. Table 1 groups the analyses of representative minerals.

\section{5.a. Amphibole and pyroxene}

Amphiboles are present in different proportions both in the green and blue layers. Amphibole chemical analyses have been recalculated on the basis of 24 oxygens and classified as glaucophane and actinolite, according to Hawthorne et al. (2012) (Table 1). Glaucophane is found as inclusions in garnet and stable along the main foliation, finally replacing omphacite; Si ranges between 7.98 and 8 atoms per formula unit (a.p.f.u.) and $\mathrm{Al}_{\text {tot }}$ varies in the range 1.61-1.90 a.p.f.u. The
Ca-amphibole actinolite overgrows garnet, omphacite and glaucophane; Si ranges between 7.55 and 8 a.p.f.u. and $\mathrm{Al}_{\text {tot }}$ varies in the range $0.09-0.29$ a.p.f.u.

Pyroxenes have been classified following Morimoto et al. (1988) (Fig. 8a, b; Table 1); relict magmatic Capyroxenes are augites and are in the order of about $1.5-2 \mathrm{~mm}$ in size; $\mathrm{Na} /(\mathrm{Na}+\mathrm{Ca})=0.04-0.05 . \mathrm{Ca}-\mathrm{Na}$ varieties are omphacite and aegirine-augite that grow either on augite, or as fine-grained crystals $(\approx 150$ $200 \mu \mathrm{m}$ sized) along the foliation; in these pyroxenes $\mathrm{Na} /(\mathrm{Na}+\mathrm{Ca})=0.26-0.54$.

\section{5.b. Garnet and epidote}

Garnet $(\approx 200-250 \mu \mathrm{m}$ sized $)$ is almandine-rich (Fig. 8c) and shows glaucophane inclusions $(\approx 10$ $15 \mu \mathrm{m}$ sized) (Fig. 6a). It is compositionally zoned with decreasing $\mathrm{Fe}$ and increasing $\mathrm{Mn}$ from the core $\left(\mathrm{X}_{\mathrm{Fe} 2+}=53 ; \mathrm{X}_{\mathrm{Mn}}=18\right)$ to the $\operatorname{rim}\left(\mathrm{X}_{\mathrm{Fe} 2+}=44 ; \mathrm{X}_{\mathrm{Mn}}=\right.$ 26) (Table 1).

Epidote $(\approx 100-150 \mu \mathrm{m}$ sized) grows together with glaucophane (3); it has been classified on the basis of the molar fractions of the end-members 
Table 1. Chemical analyses of representative minerals

\begin{tabular}{|c|c|c|c|c|c|c|c|c|c|c|c|c|c|c|c|c|c|c|}
\hline \multirow[b]{3}{*}{$\mathrm{SiO}_{2}$} & \multicolumn{5}{|c|}{ Grt } & \multicolumn{2}{|c|}{ Amph } & & & & & & & & & & Pyroxen & \\
\hline & \multirow{2}{*}{$\frac{\text { Core (a) }}{38.18}$} & Mantle (a) & \multirow{2}{*}{$\frac{\operatorname{Rim}(a)}{38.26}$} & Core (b) & \multirow{2}{*}{$\begin{array}{r}\operatorname{Rim}(b) \\
38.25\end{array}$} & \multirow{2}{*}{$\begin{array}{c}\text { Gln } \\
59.41\end{array}$} & \multirow{2}{*}{$\begin{array}{c}A c t \\
57.27\end{array}$} & \multirow[b]{2}{*}{$\mathrm{SiO}_{2}$} & \multicolumn{2}{|c|}{ Ep } & \multicolumn{2}{|c|}{ Lws } & \multicolumn{2}{|c|}{$\mathbf{W m}$} & & \multirow{2}{*}{$\begin{array}{r}\text { Omph } \\
56.22\end{array}$} & \multirow{2}{*}{$\begin{array}{l}\text { Agt } \\
54.96\end{array}$} & \multirow{2}{*}{$\frac{\mathrm{Aug}}{52.51}$} \\
\hline & & 38.54 & & 38.20 & & & & & 40.03 & 38.49 & 36.75 & 37.84 & 55.83 & 52.46 & $\mathrm{SiO}_{2}$ & & & \\
\hline $\mathrm{TiO}_{2}$ & 0.12 & 0.10 & 0.13 & 0.17 & 0.10 & 0.04 & 0.00 & $\mathrm{TiO}_{2}$ & 0.02 & 0.14 & 0.15 & 0.00 & 0.05 & 0.07 & $\mathrm{TiO}_{2}$ & 0.05 & 0.06 & 0.43 \\
\hline $\mathbf{A l}_{2} \mathbf{O}_{3}$ & 21.66 & 21.63 & 21.22 & 21.21 & 21.92 & 11.98 & 0.83 & $\mathbf{A l}_{2} \mathbf{O}_{3}$ & 34.00 & 26.26 & 30.13 & 31.46 & 19.65 & 24.50 & $\mathbf{A l}_{2} \mathbf{O}_{3}$ & 7.82 & 5.61 & 3.03 \\
\hline $\mathrm{Cr}_{2} \mathrm{O}_{3}$ & 0.00 & 0.00 & 0.01 & 0.07 & 0.00 & 0.01 & 0.00 & $\mathrm{Cr}_{2} \mathrm{O}_{3}$ & 0.07 & 0.05 & 0.39 & 0.26 & 0.00 & 0.00 & $\mathrm{Cr}_{2} \mathrm{O}_{3}$ & 0.04 & 0.86 & 1.03 \\
\hline $\mathrm{FeO}$ & 24.76 & 23.80 & 20.39 & 23.98 & 20.84 & 6.66 & 7.79 & $\mathrm{FeO}$ & 0.53 & 10.14 & 1.21 & 0.73 & 2.00 & 2.28 & $\mathrm{FeO}$ & 8.04 & 11.68 & 4.95 \\
\hline MgO & 1.05 & 0.97 & 0.79 & 0.85 & 0.89 & 11.99 & 19.26 & MgO & 0.00 & 0.02 & 0.00 & 0.17 & 6.56 & 4.57 & MgO & 8.21 & 7.48 & 15.84 \\
\hline MnO & 8.27 & 8.49 & 11.79 & 9.19 & 11.91 & 0.10 & 0.40 & MnO & 0.03 & 0.28 & 0.00 & 0.00 & 0.00 & 0.04 & MnO & 0.20 & 0.18 & 0.14 \\
\hline $\mathrm{CaO}$ & 8.88 & 9.54 & 9.73 & 8.75 & 9.22 & 0.29 & 11.32 & $\mathrm{CaO}$ & 23.98 & 23.28 & 16.86 & 17.22 & 0.04 & 0.01 & $\mathrm{CaO}$ & 12.31 & 11.74 & 21.75 \\
\hline $\mathrm{Na}_{2} \mathrm{O}$ & 0.04 & 0.04 & 0.00 & 0.06 & 0.00 & 7.48 & 1.02 & $\mathrm{Na}_{2} \mathbf{O}$ & 0.03 & 0.01 & 0.00 & 0.00 & 0.07 & 0.24 & $\mathrm{Na}_{2} \mathbf{O}$ & 7.34 & 7.73 & 0.59 \\
\hline $\mathbf{K}_{2} \mathbf{O}$ & 0.00 & 0.01 & 0.00 & 0.00 & 0.00 & 0.02 & 0.10 & $\mathbf{K}_{2} \mathbf{O}$ & 0.00 & 0.02 & 0.00 & 0.00 & 10.15 & 9.99 & $\mathbf{K}_{2} \mathbf{O}$ & 0.00 & 0.01 & 0.01 \\
\hline SUM & 102.96 & 103.11 & 102.32 & 102.48 & 103.12 & 97.97 & 97.99 & SUM & 98.69 & 98.69 & 85.49 & 87.68 & 94.35 & 94.16 & SÜM & 100.24 & 100.31 & 100.28 \\
\hline $\mathbf{S i}$ & 2.98 & 3.00 & 3.00 & 3.02 & 2.98 & 7.98 & 7.99 & $\mathbf{S i}$ & 3.00 & 3.00 & 2.01 & 2.01 & 3.73 & 3.52 & $\mathbf{S i}$ & 2.01 & 1.98 & 1.92 \\
\hline $\mathbf{T i}$ & 0.01 & 0.01 & 0.01 & 0.01 & 0.01 & 0.00 & 0.00 & $\mathbf{T i}$ & 0.00 & 0.01 & 0.01 & 0.00 & 0.00 & 0.00 & Al.IV & 0.00 & 0.02 & 0.08 \\
\hline Al & 1.99 & 1.98 & 1.96 & 1.93 & 2.01 & 1.90 & 0.14 & Al & 3.01 & 2.41 & 1.94 & 1.97 & 1.55 & 1.94 & Al.VI & 0.33 & 0.22 & 0.05 \\
\hline $\mathrm{Cr}$ & 0.00 & 0.00 & 0.00 & 0.00 & 0.00 & 0.00 & 0.00 & $\mathrm{Cr}$ & 0.00 & 0.00 & 0.02 & 0.01 & 0.00 & 0.00 & $\mathbf{T i}$ & 0.00 & 0.00 & 0.01 \\
\hline $\mathrm{Fe}$ & 1.62 & 1.55 & 1.34 & 1.54 & 1.36 & 0.75 & 0.91 & $\mathrm{Fe}$ & 0.03 & 0.59 & 0.06 & 0.03 & 0.11 & 0.13 & $\mathrm{Cr}$ & 0.00 & 0.02 & 0.03 \\
\hline Mg & 0.12 & 0.11 & 0.09 & 0.12 & 0.10 & 2.40 & 4.00 & Mg & 0.00 & 0.00 & 0.00 & 0.01 & 0.65 & 0.46 & $\mathrm{Fe}^{3+}$ & 0.16 & 0.31 & 0.02 \\
\hline Mn & 0.55 & 0.56 & 0.78 & 0.57 & 0.79 & 0.01 & 0.05 & Mn & 0.00 & 0.02 & 0.00 & 0.00 & 0.00 & 0.00 & $\mathrm{Fe}^{2+}$ & 0.08 & 0.04 & 0.13 \\
\hline $\mathrm{Ca}$ & 0.74 & 0.80 & 0.82 & 0.82 & 0.77 & 0.04 & 1.69 & $\mathrm{Ca}$ & 1.93 & 1.94 & 0.99 & 0.98 & 0.00 & 0.00 & $\mathbf{M g}$ & 0.44 & 0.40 & 0.86 \\
\hline $\mathrm{Na}$ & 0.01 & 0.01 & 0.00 & 0.00 & 0.00 & 1.95 & 0.28 & $\mathbf{N a}$ & 0.00 & 0.00 & 0.00 & 0.00 & 0.01 & 0.03 & $\mathrm{Ni}^{\circ}$ & 0.00 & 0.00 & 0.00 \\
\hline $\mathbf{K}$ & 0.00 & 0.00 & 0.00 & 0.00 & 0.00 & 0.00 & 0.02 & $\mathbf{K}$ & 0.00 & 0.00 & 0.00 & 0.00 & 0.87 & 0.86 & Mn & 0.01 & 0.01 & 0.00 \\
\hline $\mathbf{N i}$ & 0.00 & 0.00 & 0.00 & 0.00 & 0.00 & 0.00 & 0.00 & $\mathbf{N i}$ & 0.00 & 0.00 & 0.00 & 0.00 & 0.00 & 0.00 & $\mathrm{Ca}$ & 0.47 & 0.45 & 0.85 \\
\hline SUM & 8.02 & 8.01 & 8.01 & 8.01 & 8.01 & 15.04 & 15.08 & SUM & 7.98 & 7.99 & 5.01 & 5.01 & 6.93 & 6.95 & $\begin{array}{l}\mathrm{Na} \\
\mathbf{K}\end{array}$ & $\begin{array}{l}0.51 \\
0.00\end{array}$ & $\begin{array}{l}0.54 \\
0.00\end{array}$ & $\begin{array}{l}0.04 \\
0.00\end{array}$ \\
\hline $\mathbf{X}_{\mathrm{Fe} 2+}$ & 0.53 & 0.51 & 0.44 & 0.52 & 0.50 & & & Хер & 3 & 59 & & & & & Sum & 4 & 4 & 4 \\
\hline $\mathbf{X}_{\mathrm{Ca}}$ & 0.25 & 0.26 & 0.27 & 0.24 & 0.27 & & & Xczo & 97 & 41 & & & & & & & & \\
\hline$X_{M n}$ & 0.18 & 0.19 & 0.26 & 0.20 & 0.19 & & & & & & & & & & $\mathbf{X}_{\mathrm{na}}$ & 0.52 & 0.55 & 0.05 \\
\hline $\mathbf{X}_{\mathrm{Mg}}$ & 0.04 & 0.04 & 0.03 & 0.03 & 0.04 & & & & & & & & & & Q & 0.49 & 0.45 & 0.96 \\
\hline & & & & & & & & & & & & & & & Jd & 0.34 & 0.23 & 0.03 \\
\hline \multirow{9}{*}{\multicolumn{6}{|c|}{$\begin{array}{l}X e p=(F e /(F e+(A l(V I)-2)))^{*} 100 \\
X c z o=A l(V I)-2 /(A l(V I)-2+F e)^{*} 100 \\
X_{N a}=\mathrm{Na} /(\mathrm{Na}+\mathrm{Ca}) \\
X_{F e 2+}=\mathrm{Fe}^{2+} /\left(\mathrm{Ca}+\mathrm{Mg}+\mathrm{Mn}+\mathrm{Fe}^{2+}\right) \\
X_{\mathrm{Mn}}=\mathrm{Mn} /\left(\mathrm{Ca}+\mathrm{Mg}+\mathrm{Mn}+\mathrm{Fe}^{2+}\right) \\
X_{\mathrm{Mg}}=\mathrm{Mg} /\left(\mathrm{Ca}+\mathrm{Mg}+\mathrm{Mn}+\mathrm{Fe}^{2+}\right) \\
X_{\mathrm{Ca}}=\mathrm{Ca} /\left(\mathrm{Ca}+\mathrm{Mg}+\mathrm{Mn}+\mathrm{Fe}^{2+}\right) \\
Q=\mathrm{Ca}+\mathrm{Mg}+\left(\mathrm{Fe} e^{2+} /\left(\mathrm{Fe}^{2+}+\mathrm{Mg}+\mathrm{Ca}+2 \mathrm{Na}\right)\right) \\
J d=2 \mathrm{Na}\left(\left(\mathrm{AlVI} /\left(\mathrm{AlVI}+\mathrm{Fe}^{3+}\right)\right)\right. \\
\mathrm{Ae}=2 \mathrm{Na}^{*}\left(\mathrm{Fe}^{3+} /\left(\mathrm{AlVI}+\mathrm{Fe}^{3+}\right)\right)\end{array}$}} & & & & & & & & & & Ae & 0.17 & 0.32 & 0.01 \\
\hline & & & & & & & & & & & & & & & & & & \\
\hline & & & & & & & & & & & & & & & & & & \\
\hline & & & & & & & & & & & & & & & & & & \\
\hline & & & & & & & & & & & & & & & & & & \\
\hline & & & & & & & & & & & & & & & & & & \\
\hline & & & & & & & & & & & & & & & & & & \\
\hline & & & & & & & & & & & & & & & & & & \\
\hline & & & & & & & & & & & & & & & & & & \\
\hline
\end{tabular}



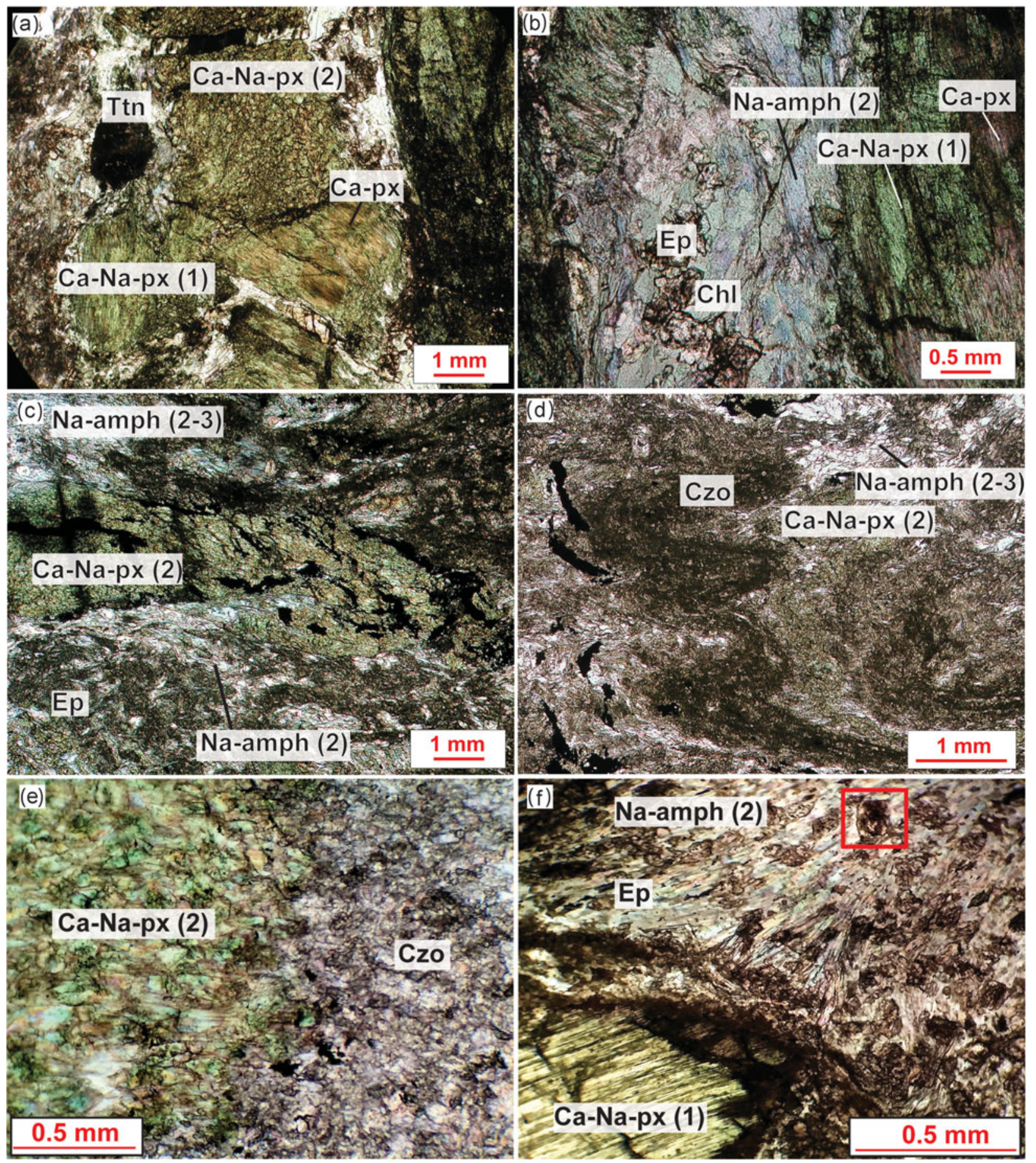

Figure 5. (Colour online) Photomicrographs of representative minerals and structures in the metagabbro. (a) Ca-Na-pyroxene grows first statically replacing magmatic pyroxene relics; $\mathrm{Ca}-\mathrm{Na}$-pyroxene later recrystallizes as subgrains (uppermost part of the picture). Na-amphibole overgrows Ca-Na-pyroxene. (b) Porphyroclast of magmatic pyroxene replaced by $\mathrm{Ca}-\mathrm{Na}$-pyroxene and by later Naamphibole. (c) Fold hinge in a Ca-Na-pyroxene-rich layer; here pyroxene forms syn-kinematic subgrains. (d) Folds deforming the $\mathrm{Ca}-\mathrm{Na}$-pyroxene-rich and the clinozoisite-rich layers. (e) Epidote replacing $\mathrm{Ca}-\mathrm{Na}$-pyroxene. (f) Pressure shadows of glaucophane growing from the $\mathrm{Ca}-\mathrm{Na}$-pyroxene; the red box depicts the area shown in Figure 6b, where lawsonite occurs.

in the epidote solid solutions series (clinozoisite and epidote); they were calculated respectively as: $\mathrm{X}_{\mathrm{cz}}=\mathrm{Al}^{(\mathrm{VI})}-2 /\left(\left(\mathrm{Al}^{(\mathrm{VI})}-2\right)+\mathrm{Fe}^{3+}\right) ; \mathrm{X}_{\mathrm{ep}}=$ $\mathrm{Fe}^{3+} /\left(\left(\mathrm{Al}^{(\mathrm{VI})}-2\right)+\mathrm{Fe}^{3+}\right)$.

The chemical composition of epidote varies between the clinozoisite $\left(\mathrm{X}_{\mathrm{ep}}=3\right)$ and the Fe-rich epidote endmembers $\left(X_{\mathrm{ep}}=59\right)$ (Table 1$)$.

\section{5.c. Lawsonite and white mica}

Preserved lawsonite $(\approx 10-15 \mu \mathrm{m}$ sized) has been classified on the basis of 8 oxygens (Table 1 ) and shows an almost pure composition with Fe content in the range of $0.02-0.06$ a.p.f.u.; it grows in pressure shadows (around $\mathrm{Ca}-\mathrm{Na}$-pyroxene) made of glaucophane and is replaced by later albite. 

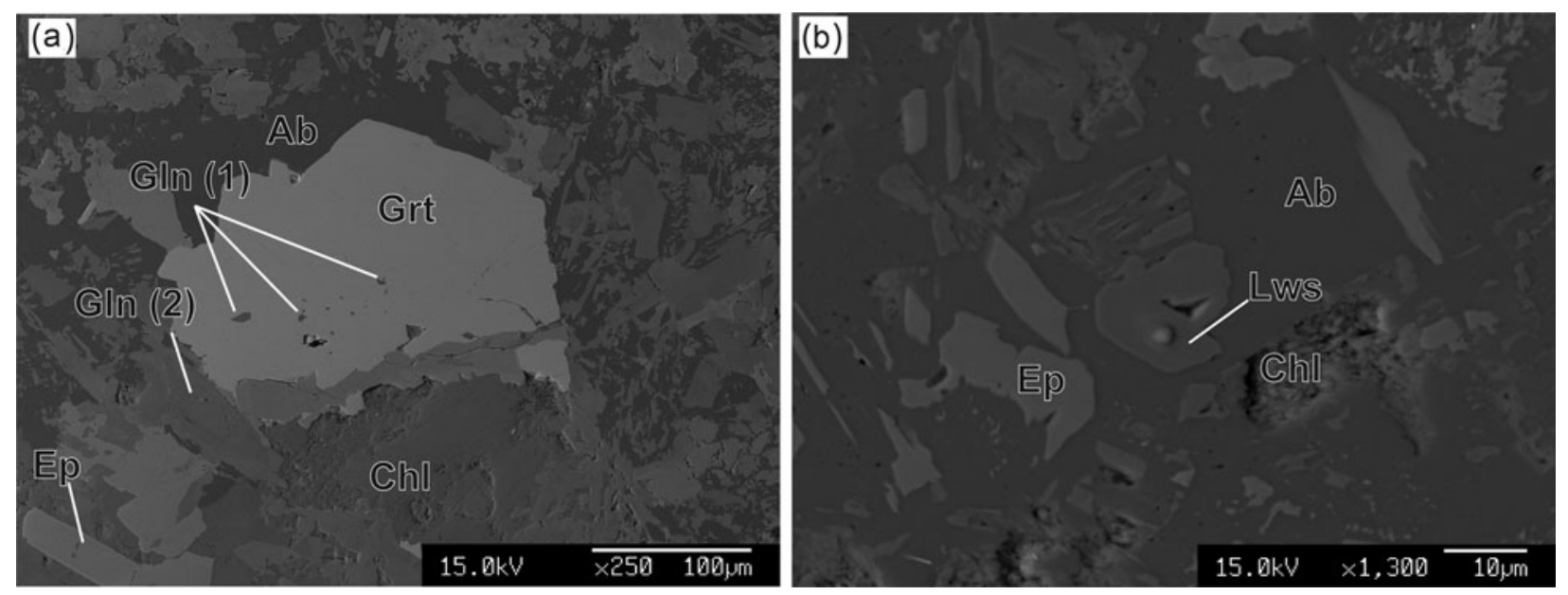

Figure 6. (a) Back-scattered electron (BSE) image of a garnet crystal replaced by epidote, chlorite and albite. (b) BSE image of a lawsonite crystal surrounded by albite; the dot inside the lawsonite crystal is the analysis point.

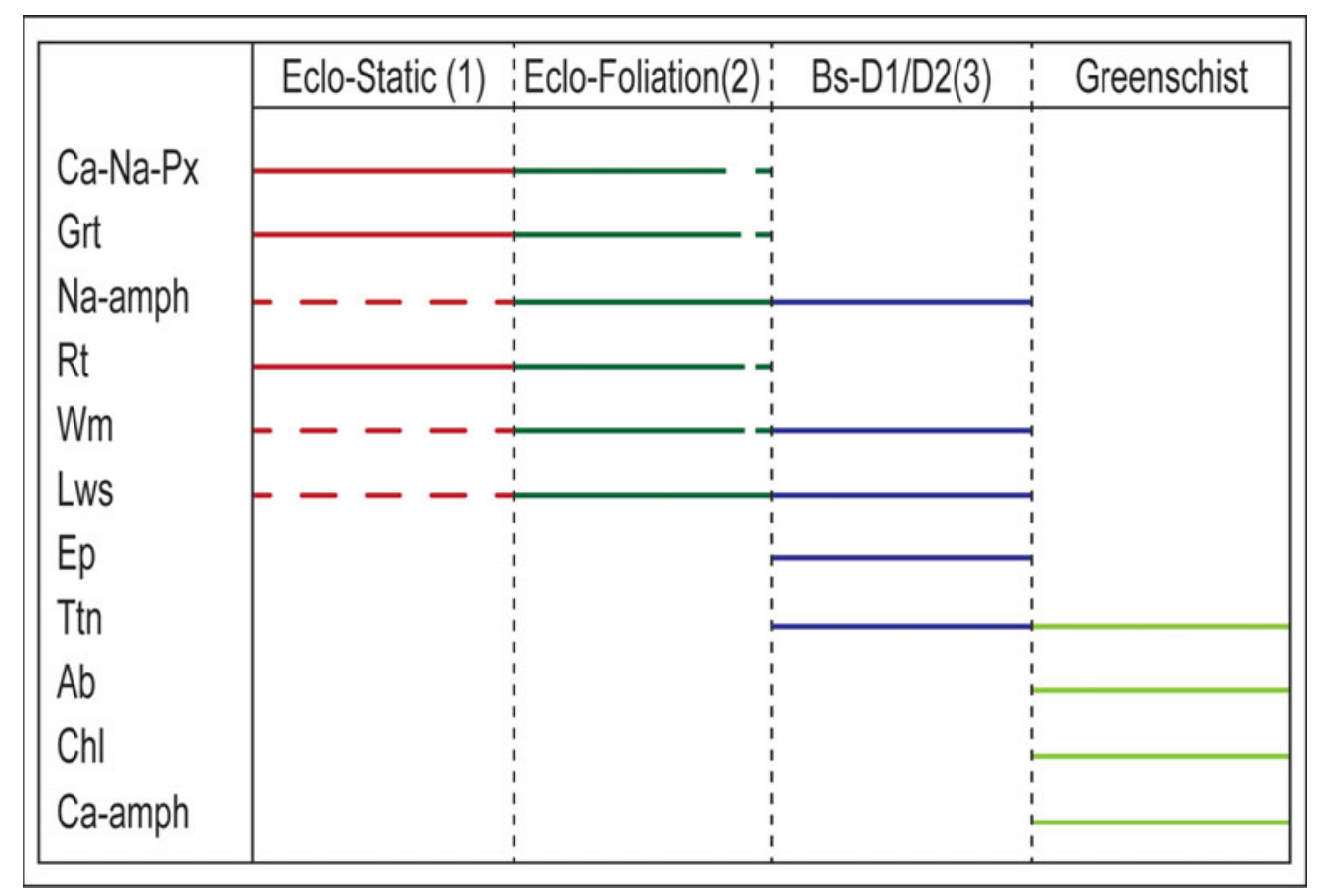

Figure 7. (Colour online) Phase crystallization diagram showing the minerals stability along the metamorphic path. Eclo - eclogitic facies; Bs - blueschist facies; the progressive numbers represent the parageneses; D1 and D2 are the two main deformational events.

White mica composition has been calculated on the basis of 11 oxygens and considering iron as $\mathrm{Fe}^{2+}$. White mica occurs as fine-grained crystals of phengite with Si content ranging between 3.55 and 3.77 a.p.f.u. and $\left(\mathrm{Mg}+\mathrm{Fe}_{\mathrm{tot}}\right)=0.59-0.77$ a.p.f.u.; the phengite compositions lie very close to the celadonitemuscovite compositional joint, reflecting the important role of Tschermak's substitution and confirming that almost no $\mathrm{Fe}^{3+}$ occurs (Vidal \& Parra, 2000; Groppo et al. 2016).

\section{6. $P-T$ estimates}

We used a thermodynamic modelling approach to assess the $P-T$ evolution of the metagabbro body and to constrain its metamorphic peak conditions. $P-T$ pseudosections were calculated using Perple_X (http: //www.perplex.ethz.ch; Connolly, 1990) for the system KMnTiNCFMASH with $\mathrm{H}_{2} \mathrm{O}$ considered in excess $\left(\mathrm{aH}_{2} \mathrm{O}=1\right)($ Table 2$)$.

The bulk-rock composition of the rock was determined by inductively coupled plasma mass spectrometry (ICP-MS) analysis at Activation Laboratories Ltd (Ontario, Canada). The thermodynamic dataset and equation of state for $\mathrm{H}_{2} \mathrm{O}-\mathrm{CO}_{2}$ fluid of Holland \& Powell (1998, revised 2002) were implemented. We used the following solid solutions: garnet (Holland \& Powell, 1998), amphibole (Wei \& Powell, 2003; White, Powell \& Phillips, 2003), omphacite (Holland \& Powell, 1996), chlorite (Holland, Baker \& Powell, 1998), phengite (Holland \& Powell, 1998) and epidote (Holland \& Powell, 1998). 


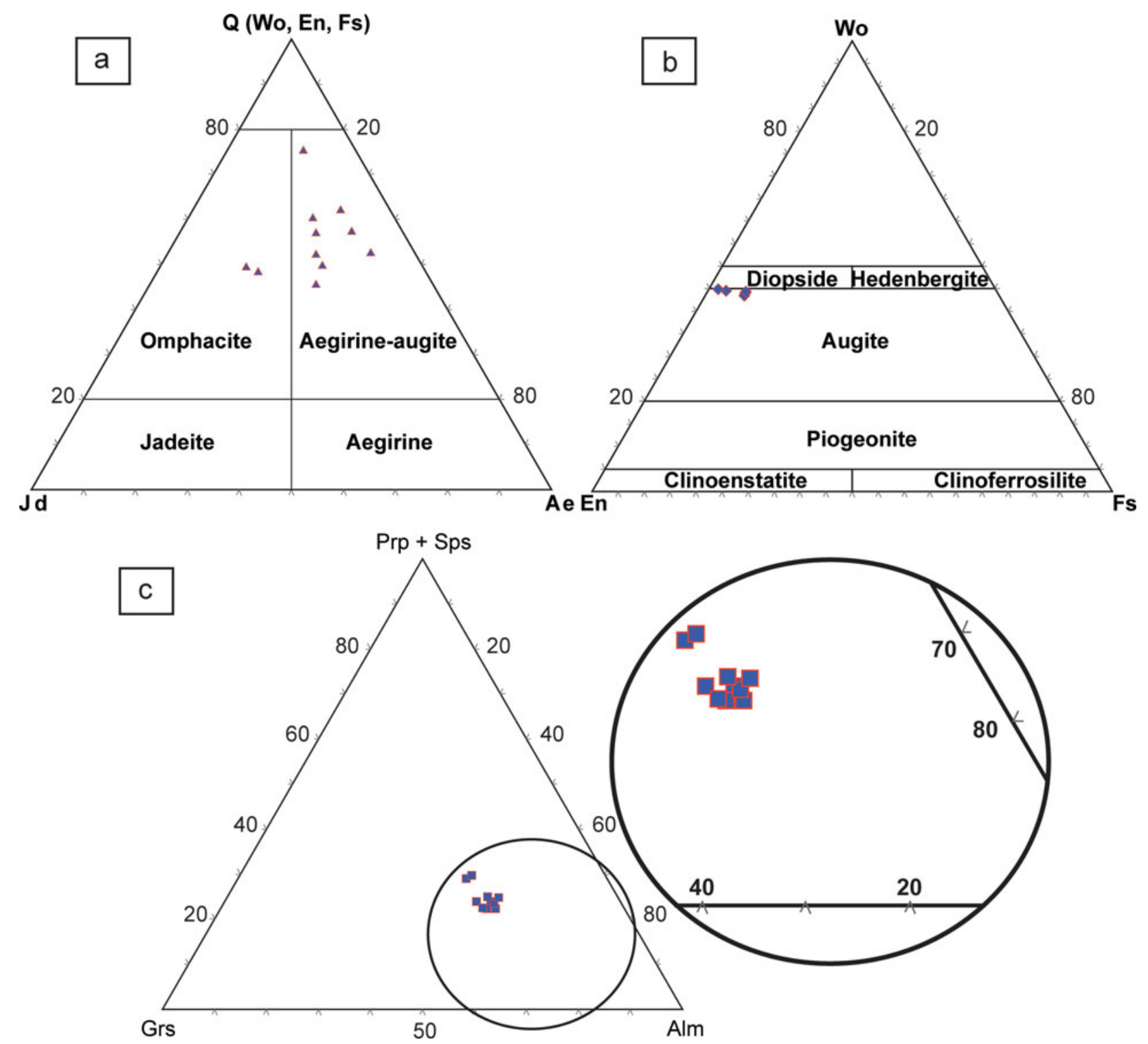

Figure 8. (Colour online) Classification diagrams of representative minerals. (a, b) Na- $+\mathrm{Ca}-\mathrm{Na}$ - and $\mathrm{Ca}-\mathrm{Mg}-\mathrm{Fe}-\mathrm{pyroxene}$, respectively (after Morimoto et al. 1988). (c) Garnet classification diagram.

Table 2. Bulk-rock compositions of sample SC37 (lawsonite-bearing metagabbro)

\begin{tabular}{lccr}
\hline Weight \% & Detection limit & $\begin{array}{c}\text { SC37 } \\
H_{2} \text { O excess }\end{array}$ & $\begin{array}{c}\text { SC37 } \\
\text { With LOI }\end{array}$ \\
\hline $\mathbf{S i O}_{2}$ & 0.01 & 50.31 & 48.13 \\
$\mathbf{A l}_{2} \mathbf{O}_{3}$ & 0.01 & 17.89 & 17.11 \\
$\mathbf{F e O}$ & 0.01 & 7.34 & 7.02 \\
$\mathbf{M n O}$ & 0.001 & 0.12 & 0.11 \\
$\mathbf{M g O}$ & 0.01 & 8.98 & 8.59 \\
$\mathbf{C a O}$ & 0.01 & 10.87 & 10.40 \\
$\mathbf{N a} \mathbf{O}$ & 0.01 & 3.72 & 3.56 \\
$\mathbf{K}_{2} \mathbf{O}$ & 0.01 & 0.06 & 0.06 \\
$\mathbf{T i O}_{2}$ & 0.001 & 0.72 & 0.69 \\
$\mathbf{L O I}$ & & 0.00 & 4.33 \\
Total & & 100 & 100 \\
\hline
\end{tabular}

Since the used analytical method for defining the bulk-rock composition cannot estimate the real proportion between ferrous and ferric iron, and in order to account for the occurrence of epidote, we simulated pseudosections with various hypothetical $\mathrm{Fe}^{3+}$ amounts (i.e. $\mathrm{Fe}_{2} \mathrm{O}_{3}=10 \%-20 \% \mathrm{Fe}_{\text {tot }}$ ). The compositional isopleths calculated for garnet cores in the pseudosections with $\mathrm{Fe}_{2} \mathrm{O}_{3}=10 \%-20 \% \mathrm{Fe}_{\text {tot }}$ diverged from each other suggesting that the considered bulk composition did not fit the rock composition during garnet growth. We thus neglected $\mathrm{Fe}^{3+}$ and simulated the pseudosection shown in Figure 9a and Figure S1 (online Supplementary Material available at http://journals.cambridge.org/geo) that includes tri- to esavariant fields. The compositional isopleths calculated for garnet cores $\left(\mathrm{X}_{\mathrm{Fe} 2+}=0.53, \mathrm{X}_{\mathrm{Ca}}=\right.$ $\left.0.25, \mathrm{X}_{\mathrm{Mn}}=0.18, \mathrm{X}_{\mathrm{Mg}}=0.04\right)$ in the free-Fe ${ }^{3+}$ pseudosection define their growth conditions in the range $465-477^{\circ} \mathrm{C}$ and $20.9-24.4 \mathrm{kbar}$ and cross-cut into the field where chl $+\mathrm{Ca}-\mathrm{Na}-\mathrm{px}+\mathrm{wm}+2 \mathrm{Na}-$ $\mathrm{amph}+\mathrm{grt}+\mathrm{lws}+\mathrm{rt}$ occur (the mineral abbreviations are after Kretz, 1983, except for $\mathrm{Ca}-\mathrm{Na}-\mathrm{px}=\mathrm{Ca}-$ Na-pyroxene, Na-amph $=$ Na-amphibole and $\mathrm{wm}=$ white mica). This confirms that the amount of $\mathrm{Fe}^{3+}$ in 

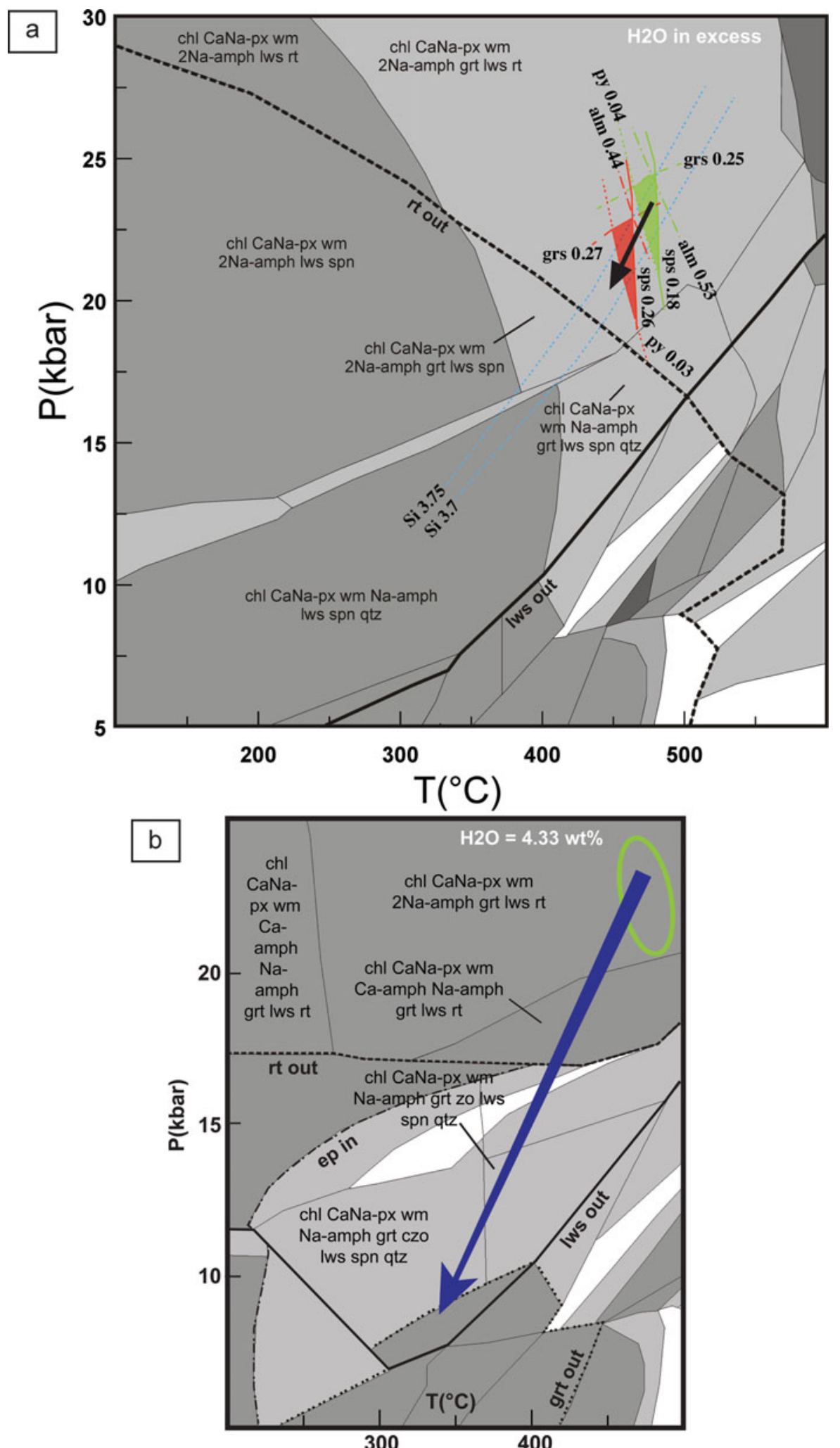

Figure 9. (Colour online) $P-T$ pseudosections in the KMnTiNCFMASH system. The mineral abbreviations are after Kretz (1983) except for: cpx - clinopyroxene; Na-amph - Na-amphibole; Ca-amph - Ca-amphibole; wm - white mica; and Ca-Na-px - Ca-Napyroxene. Narrow and small fields have been ignored for the sake of clarity. (a) $P-T$ pseudosection with $\mathrm{H}_{2} \mathrm{O}$ in excess. The stability conditions of the garnet core and rim are shown by green and red fields, respectively. The dotted light blue lines are isopleths of $\mathrm{Si}$ in white mica. The arrow shows the first stage of the retrograde path along a $3{ }^{\circ} \mathrm{C} \mathrm{km}^{-1}$ gradient. (b) $P-T$ pseudosection with undersaturated conditions $\left(\mathrm{H}_{2} \mathrm{O}=\mathrm{LOI}\right)$. The peak metamorphic conditions are highlighted by the green circle. The blue arrow depicts the later stages of the retrograde path with coexisting lawsonite and epidote. 
the rock is closer to $0 \% \mathrm{Fe}_{\text {tot }}$ than to $10 \% \mathrm{Fe}_{\text {tot }}$. The compositional isopleths of $\mathrm{Si}$ in mica $(\mathrm{Si}=3.70-3.75$ a.p.f.u.) fit the isopleths of the garnet core testifying to the growth of high-pressure mica. In the pseudosection, the amount of chlorite at the $P-T$ conditions defined by garnet growth is $13 \mathrm{wt} \%$. The occurrence in our sample of chlorite stable at peak metamorphic conditions is difficult to estimate, since chlorite recrystallized at lower $P-T$ conditions, probably erasing its former stability relations. The mineralogical association described in the above field, however, well represents the metamorphic peak assemblage that we observe in the rock; this field also includes lawsonite, which is presently observed in the Na-amphibole pressure shadows growing from $\mathrm{Ca}-\mathrm{Na}$-pyroxene. Since the garnet chemical zonation is minor, we think that the fractionation effect on the bulk composition of the system is very low; we thus used the composition of the garnet rim to trace the $P-T$ evolution of the rock. The compositional isopleths of the garnet rim $\left(\mathrm{X}_{\mathrm{Fe} 2+}=0.44, \mathrm{X}_{\mathrm{Ca}}=\right.$ $\left.0.27, \mathrm{X}_{\mathrm{Mn}}=0.26, \mathrm{X}_{\mathrm{Mg}}=0.03\right)$ constrain the growing conditions at about $448-465^{\circ} \mathrm{C}$ and $19.3-22.8 \mathrm{kbar}$, at lower $P-T$ compared to the one predicted by the garnet core.

The $P-T$ fields derived from the stability conditions of the garnet core and rim (Fig. 9a) define a possible initial retrogression path of the eclogitic metagabbro body (arrow in Fig. 9a) along a very low thermal gradient $\left(3{ }^{\circ} \mathrm{C} \mathrm{km}{ }^{-1}\right)$. This value (i.e. $\left.3^{\circ} \mathrm{C} \mathrm{km}^{-1}\right)$ results from the thermobaric gradient of the path later transformed, according to the lithostatic pressure $\left(0.3 \mathrm{kbar} \mathrm{km}^{-1}\right)$, into a thermal gradient.

The later retrogressive stages are defined in our rock by the coexistence of lawsonite, Na-amphibole and epidote; this assemblage is, however, not represented in the fields of the pseudosection that we calculated with $\mathrm{H}_{2} \mathrm{O}$ in excess. To understand the possible role of $\mathrm{H}_{2} \mathrm{O}$ in the stability of this retrograde assemblage, we calculated the stability fields for the free- $\mathrm{Fe}^{3+}$ bulk-rock composition along the geotherm defined for the above exhumation path (i.e. $\left.3{ }^{\circ} \mathrm{C} \mathrm{km}^{-1}\right)$. The $\mathrm{P} / \mathrm{T} \mathrm{X}\left(\mathrm{H}_{2} \mathrm{O}\right)$ pseudosection (Fig. S2, online Supplementary Material available at http://journals.cambridge.org/geo) shows that, in order to obtain the simultaneous stability of lawsonite and epidote, under-saturated conditions should occur. The transition from $\mathrm{H}_{2} \mathrm{O}$ in excess (at peak metamorphic conditions) to under-saturated conditions (during the retrograde path) could be explained with $\mathrm{H}_{2} \mathrm{O}$ request by lawsonite during its growth; the subtraction of $\mathrm{H}_{2} \mathrm{O}$ from the system (i.e. undersaturated system) allowed the simultaneous occurrence of lawsonite and epidote in the system as observed by Poli \& Schmidt (1997). This has been extensively evaluated using pseudosections by Ballevre, Pitra \& Bohn (2003), López-Carmona, Pitra \& Abati (2013), LópezCarmona et al. (2014) and Groppo et al. (2016).

The P-X $\left(\mathrm{CO}_{2}\right)$ pseudosection (Fig. S3, online Supplementary Material available at http://journals. cambridge.org/geo), calculated at $T=400^{\circ} \mathrm{C}$, reveals that lawsonite is stable in the range $P=11-25 \mathrm{kbar}$, for
$\mathrm{X}\left(\mathrm{CO}_{2}\right)<0.015\left(\right.$ with $\left.\mathrm{X}\left(\mathrm{CO}_{2}\right)=\mathrm{CO}_{2} /\left(\mathrm{CO}_{2}+\mathrm{H}_{2} \mathrm{O}\right)\right)$; for $\mathrm{X}\left(\mathrm{CO}_{2}\right)$ in the range $0.0013-0.015$ lawsonite occurs together with carbonates.

Since in our samples we observed the sole presence of lawsonite (without carbonates), according to the above $\mathrm{P}-\mathrm{X}\left(\mathrm{CO}_{2}\right)$ pseudosection, $\mathrm{X}\left(\mathrm{CO}_{2}\right)$ in the fluid should be $<0.13 \%$ of the total loss on ignition (LOI). To trace the retrograde exhumation path we thus neglected $\mathrm{CO}_{2}$ and simulated an under-saturated system considering the $\mathrm{LOI}(\mathrm{LOI}=4.33 \mathrm{wt} \%)$ as pure water (Fig. 9b and Fig. S4 in the online Supplementary Material available at http://journals.cambridge.org/geo).

The path in Figure $9 \mathrm{~b}$ passes through fields where lawsonite coexists with epidote, crossing the rutile breakdown reaction $(P<15 \mathrm{kbar})$.

The metagabbro body thus experienced different $\mathrm{H}_{2} \mathrm{O}$ contents: at eclogitic metamorphic peak conditions $\left(T=465-477^{\circ} \mathrm{C}\right.$ and $\left.P=20.9-24.4 \mathrm{kbar}\right)$, $\mathrm{H}_{2} \mathrm{O}$ was continuously supplied to the system, allowing lawsonite formation; the retrograde history was marked by the decrease of water content and undersaturated conditions, with the occurrence of both lawsonite and epidote.

\section{Discussion}

\section{7.a. Occurrence of a lawsonite-bearing eclogitic} metagabbro in the Voltri Massif

The lawsonite-bearing eclogitic metagabbro $(\mathrm{Ca}-$ $\mathrm{Na}-\mathrm{px}+$ garnet $+\mathrm{gln}+\mathrm{rt}+\mathrm{ph}+\mathrm{lws}$ ) studied in this paper is an unusual lithology, as lawsonite is rarely preserved in a strongly deformed rock that records high-pressure metamorphic peak conditions, as the studied metagabbro is. Davis \& Whitney (2006) and Vitale Brovarone et al. (2011) in fact proposed that fresh lawsonite eclogites are preserved only in domains unaffected by post-eclogitic deformation, which prevents high-pressure mineral retrogression; we, however, observed that lawsonite grows also along the mylonitic foliation in $\mathrm{Ca}-\mathrm{Na}$-pyroxene pressure shadows. Lawsonite-bearing eclogites are reported only in a few outcrops of the Voltri Massif: lawsonite occurs as pseudomorphs replaced by aggregates of epidote + paragonite + chlorite \pm phengite in eclogitic metagabbro of the eastern sector of the Voltri Massif (i.e. Mt Pesucco outcrop, Malatesta et al. 2012a ; 'Prato del Gatto' and 'Case Buzzano' eclogitic metagabbro, Capponi \& Crispini, 2008a).

In the Cascine Parasi outcrop, about $3.5 \mathrm{~km}$ distance from our study zone, eclogite metagabbro boulders in a tectonic mélange show high-pressure assemblages with preserved stable lawsonite (Federico et al. 2007b). In the same outcrop, eclogite metagabbro and metasediment bodies include aggregates interpreted as pseudomorphs after lawsonite (Cortesogno et al. 1981; Federico et al. 2007b).

Most of the worldwide lawsonite eclogites are blocks intimately associated with serpentinites, as in our case; some of them are instead coherent units 
associated with blueschist, orthogneiss or paragneiss (Tsujimori et al. $2006 a$ and references therein; Vitale Brovarone et al. 2011). The assemblage observed in our lawsonite-bearing eclogitic metagabbro and the estimated metamorphic peak conditions $(T=$ 465-477 ${ }^{\circ} \mathrm{C}$ for $P=20.9-24.4 \mathrm{kbar}$ ) are comparable with what is observed in worldwide lawsonite eclogites in serpentinites; they usually preserve a general prograde assemblage with grt + omp + $\mathrm{lws}+\mathrm{wm}+\mathrm{qtz} \pm \mathrm{rt} \pm \mathrm{ttn} \pm \mathrm{gln} \pm \mathrm{chl} \pm \mathrm{tlc}$, recording peak pressure in the range $14-30 \mathrm{kbar}$ and temperature between 360 and $570^{\circ} \mathrm{C}$ (Tsujimori et al. 2006a,b; Tsujimori \& Ernst, 2014 and references therein; Davis \& Whitney, 2006). We have little evidence about the prograde path of our samples, except for glaucophane inclusions in garnet, that testify to its possible occurrence also at metamorphic peak conditions. Eclogites and eclogitic metabasalts of Alpine Corsica show metamorphic peak assemblages $\quad$ grt + omp $+\mathrm{ph}+\mathrm{gln}+\mathrm{lws}+\mathrm{qtz}+\mathrm{ttn}+\mathrm{opq}$, Ravna et al. 2010 and references therein; $\mathrm{omp}+\mathrm{lws}+\mathrm{grt}+\mathrm{ph}+\mathrm{ttn} \pm \mathrm{gln} \pm \mathrm{act} \pm \mathrm{chl}, \quad$ Vitale Brovarone et al. 2011; abbreviations are after Whitney \& Evans, 2010) stable at $c .390^{\circ} \mathrm{C}$ at $2.05 \mathrm{GPa}$ for eclogites, and $340-415^{\circ} \mathrm{C}, 1.9-2.6 \mathrm{GPa}$ (Ravna et al. 2010) or $520 \pm 20^{\circ} \mathrm{C}$ and $2.3 \pm 0.1 \mathrm{GPa}$, for the eclogitic metabasalts (Vitale Brovarone et al. 2011).

The peak assemblages proposed for the Roboaro lawsonite-bearing eclogitic metagabbro are particularly similar to lawsonite eclogites from South Motagua (Guatemala; Tsujimori et al. 2006b), the Central Pontides (Turkey; Altherr et al. 2004) and the Sivrihisar Massif (Turkey; Davis \& Whitney, 2006), even if the stability conditions are mostly comparable to the South Motagua lawsonite eclogites $(1.8-2.5 \mathrm{GPa}$ and $\left.290-470^{\circ} \mathrm{C}\right)$.

The development and preservation of lawsonite in rocks that experienced high-pressure conditions requires both cold subduction and a rapid exhumation (Tsujimori et al. 2006a,b; Çetinkaplan et al. 2008). Lawsonite is an important carrier of water and trace elements to high depths (at least $300 \mathrm{~km}$ in cold subduction zones): it accommodates up to $11.5 \mathrm{wt} \%$ of $\mathrm{H}_{2} \mathrm{O}$ that can be released from the slab, providing volatiles for arc magmatism and subduction zone seismicity (Schmidt \& Poli, 1998; Tsujimori et al. 2006a,b and references therein).

The preservation of lawsonite in the rocks along the Roboaro River suggests that at least one of these conditions (i.e. cold subduction and rapid exhumation) has been verified. Concerning the first hypothesis (i.e. cold subduction), thermodynamic modelling suggests that the metagabbro body reached peak metamorphic conditions at a relatively low temperature $\left(T=465-477{ }^{\circ} \mathrm{C}\right.$ for $\left.P=20.9-24.4 \mathrm{kbar}\right)$, in a setting where $\mathrm{H}_{2} \mathrm{O}$ was continuously provided to a cold system. Spandler \& Pirard (2013) suggested that the maximum $P-T$ conditions reached by lawsonite eclogites may not necessarily reflect the general conditions of cold subduction: as the shallow fore-arc mantle is cooler than the deep sub-arc mantle wedge, the top of the subducting slab undergoes rapid heating after coupling with the hot asthenospheric mantle wedge. The preservation of lawsonite eclogite can suggest that they were exhumed prior to heating of the slab by the overlying asthenosphere and were not related to a general cold subduction.

Concerning the exhumation rate, even if a rapid exhumation has been proposed for the preservation of lawsonite in high-pressure rocks Tsujimori et al. (2006a), Agard et al. (2009) suggested that lawsonite can survive at slow exhumation rates if refrigerant conditions are maintained. Proposed exhumation rates for eclogite and blueschist rocks of the Voltri Massif range from $3.3-3.9 \mathrm{~mm} \mathrm{y}^{-1}$ (Federico et al. 2005) to $25 \mathrm{~mm} \mathrm{y}^{-1}$ (Rubatto \& Scambelluri, 2003); the latter velocity has been recalculated by C. Malatesta (unpub. Ph.D. thesis, Univ. degli Studi di Genova, 2011) and attests to values of $10-12 \mathrm{~mm} \mathrm{y}^{-1}$, considering an exhumation time of $4 \mathrm{Ma}$. The exhumation rates proposed for the Voltri Massif are therefore in general low values and seem to confirm that lawsonite is preserved thanks to cold conditions during subduction rather than a rapid exhumation.

\section{7.b. $\mathrm{CO}_{2}$-rich fluids and fluid-rock interaction}

The occurrence of carbonated serpentinites, wrapping the eclogitic metagabbro and metasediment bodies, suggests that an intense and long-lasting circulation of $\mathrm{CO}_{2}$-rich fluids affected the area around the Roboaro River and the adjacent zones. The country-rock serpentinites show various degrees of carbonation until their complete transformation into listvenites. Serpentinites are replaced by carbonate minerals starting preferentially from veins that either follow the pervasive foliation or from mesh structures; carbonates also grow along late fracture systems. All these structures acted as preferential pathways for the infiltration of $\mathrm{CO}_{2}$-bearing fluids during subduction.

The occurrence of listvenites and carbonated serpentinites mainly along fault zones (Fig. 1b) also confirms the structural control of fluid circulation along shear zones and the damage zone of faults.

Further evidence on the circulation of $\mathrm{CO}_{2}$-rich fluids comes from an outcrop some hundreds of metres from the Roboaro River study area (i.e. La Pesca locality). At this site, Cortesogno, Galbiati \& Principi (1980), Cortesogno, Lucchetti \& Massa (1981) and Scambelluri et al. (2016) described a garnet-bearing marble interlayered with serpentinite, dolomite and hybrid-rocks (the latter intermediate between serpentinite and marble). These rocks have been interpreted either as ophicarbonate bodies formed on an ancient ocean-floor (Cortesogno, Galbiati \& Principi, 1981) or as a serpentinite-marble contact; in both cases these rocks were highly deformed and metamorphosed during the high-pressure subduction history (Scambelluri et al. 2016). Studying these rocks, Scambelluri et al. (2016) hypothesized that $\mathrm{CO}_{2}$ fluid circulation, and 
therefore the formation of high- $P$ ophicarbonate, was linked to the dehydration of serpentinite close to metamorphic peak conditions; the released aqueous fluids triggered the breakdown of dolomite in the nearby marbles and this reaction discharged $\mathrm{C}$ into the fluids.

In the Roboaro River study area, we have no direct analogies with the outcrop cited above and therefore we do not have clear constraints about the timing of $\mathrm{CO}_{2}$ fluid circulation into the serpentinites.

No evidence (e.g. carbonates, carbonate-bearing veins) of a strong interaction of the $\mathrm{CO}_{2}$-rich fluids with the lawsonite-bearing eclogitic metagabbro at high-pressure conditions occurs; this is in accordance with the results of the pseudosections calculation (Section 6; Fig. S4, online Supplementary Material available at http://journals.cambridge.org/ geo), suggesting that lawsonite is stable in the system for very low contents of $\mathrm{CO}_{2}$ (i.e. $\mathrm{X}\left(\mathrm{CO}_{2}\right)<$ $0.13 \mathrm{wt} \%)$.

At the current state of knowledge of the area, the reasons why the lawsonite-bearing eclogitic metagabbro escaped from an intense $\mathrm{CO}_{2}$ fluid circulation are still puzzling; nonetheless some reasonable scenarios could be envisaged: (i) the lawsonite-bearing eclogitic metagabbro and host-rocks have contrasting rheologies and permeabilities; (ii) the lithotypes (i.e. eclogitic metagabbro versus serpentinite) are characterized by different chemical affinities with $\mathrm{CO}_{2}$-bearing fluids; (iii) the $\mathrm{CO}_{2}$-bearing fluid circulation pre-dated the coupling of the lawsonite-bearing eclogitic metagabbro with serpentinite.

\section{7.c. Geodynamic implications}

The area along the Roboaro River is an example of a hydrated slab portion where both aqueous fluids and carbonate-rich fluids were active. This area of the Voltri Massif recorded multiple superposed deformations, related to a general shear regime. The alternation of Na-amphibole-rich and $\mathrm{Ca}-\mathrm{Na}$-pyroxene-rich layers in the eclogitic metagabbro body and the concurrent interfolding of the metagabbro with the metasediment lens and serpentinite are one of the most evident effects of deformation (Fig. 10).

$\mathrm{Na}$-amphibole-rich and $\mathrm{Ca}-\mathrm{Na}$-pyroxene-rich layers could derive, respectively, from the hydrous rim and the anhydrous core of mafic lenses incorporated inside serpentinite country-rock, as suggested for metabasalts of the Zermatt-Saas ophiolite by Angiboust \& Agard (2010). At the present stage, it is not possible to assess if the amphibole-rich rim reflects an oceanic stage of hydration of the outermost rim of mafic bodies inside the ultramafic serpentinized basement, or a later interaction of the boudinaged mafic bodies with fluids during the subduction path.

The ductile shear regime that affected this area strongly acted at least from eclogite-facies metamorphic conditions inside the subduction zone, deforming the $\mathrm{Ca}-\mathrm{Na}$-pyroxene + garnet association in the metagabbro, and continued to be active at blueschist-facies conditions, during the exhumation stage. The shear regime also enhanced the circulation of $\mathrm{CO}_{2}$-rich fluids through the country-rock serpentinite, triggering its partial to total carbonation and transformation into listvenite. The following brittle-ductile structures affecting the metagabbro (i.e. boudinage and low-angle shearing surfaces) formed during late-stage greenschist-facies conditions.

The occurrence of preserved lawsonite coupled with the petrological study suggest that this area underwent different $P-T$ conditions (lower $T$ ) compared to most of the Voltri Massif, where eclogite metagabbros record in general a peak temperature higher than $500^{\circ} \mathrm{C}$ (Scambelluri et al. 1991; Federico et al. 2004; Vignaroli et al. 2005); exceptions are the eclogites studied by Liou et al. (1998) and Brouwer, Vissers \& Lamb (2002), that record $T=450{ }^{\circ} \mathrm{C}$ for $P=18 \mathrm{kbar}$, and the eclogite studied by Malatesta et al. (2012a), with peak $T=460-500^{\circ} \mathrm{C}$ and $P=22-28 \mathrm{kbar}$; in all these cases, however, lawsonite is absent or is destabilized and occurs as pseudomorphs, suggesting that these eclogites followed hotter exhumation paths.

Accordingly to what was proposed by Spandler \& Pirard (2013) for lawsonite-bearing high-pressure rocks, this area could represent a portion of the top of the subducted slab, close to the plate interface: this slab portion was coupled with a hydrated and 'cool' mantle wedge that kept our eclogitic metagabbro in a low-temperature regime with the preservation of lawsonite.

The different $P-T$ paths identified for the eclogites of the Voltri Massif confirm that it is made up by rock bodies subducted to various depths and brought to the surface along different exhumation trajectories. Moreover, the occurrence of rocks with different paleogeographic origins (e.g. ocean versus continent) in a serpentinite matrix requires a large-scale mechanism that could associate them. As suggested by Federico et al. (2007a) and Malatesta et al. (2012a,b), the geodynamic mechanism responsible for these kinds of assemblages and their evolution could be involvement in a low-viscosity serpentinite channel close to the plate interface.

\section{Main remarks}

This work presents a detailed structural, petrographical and petrological study of the Roboaro River area (Voltri Massif, Ligurian Western Alps). The occurrence of a lawsonite-bearing eclogite folded together with metasediments and variously carbonated serpentinites allowed us to interpret this area as an example of a highly hydrated slab portion, where both aqueous fluids and carbonate-rich fluids were present at highpressure conditions.

The lawsonite-bearing metagabbro body reached eclogitic metamorphic peak conditions at $T=465$ $477^{\circ} \mathrm{C}$ and $P=20.9-24.4 \mathrm{kbar}$, with $\mathrm{H}_{2} \mathrm{O}$ continuously supplied to the system. The exhumation path was 

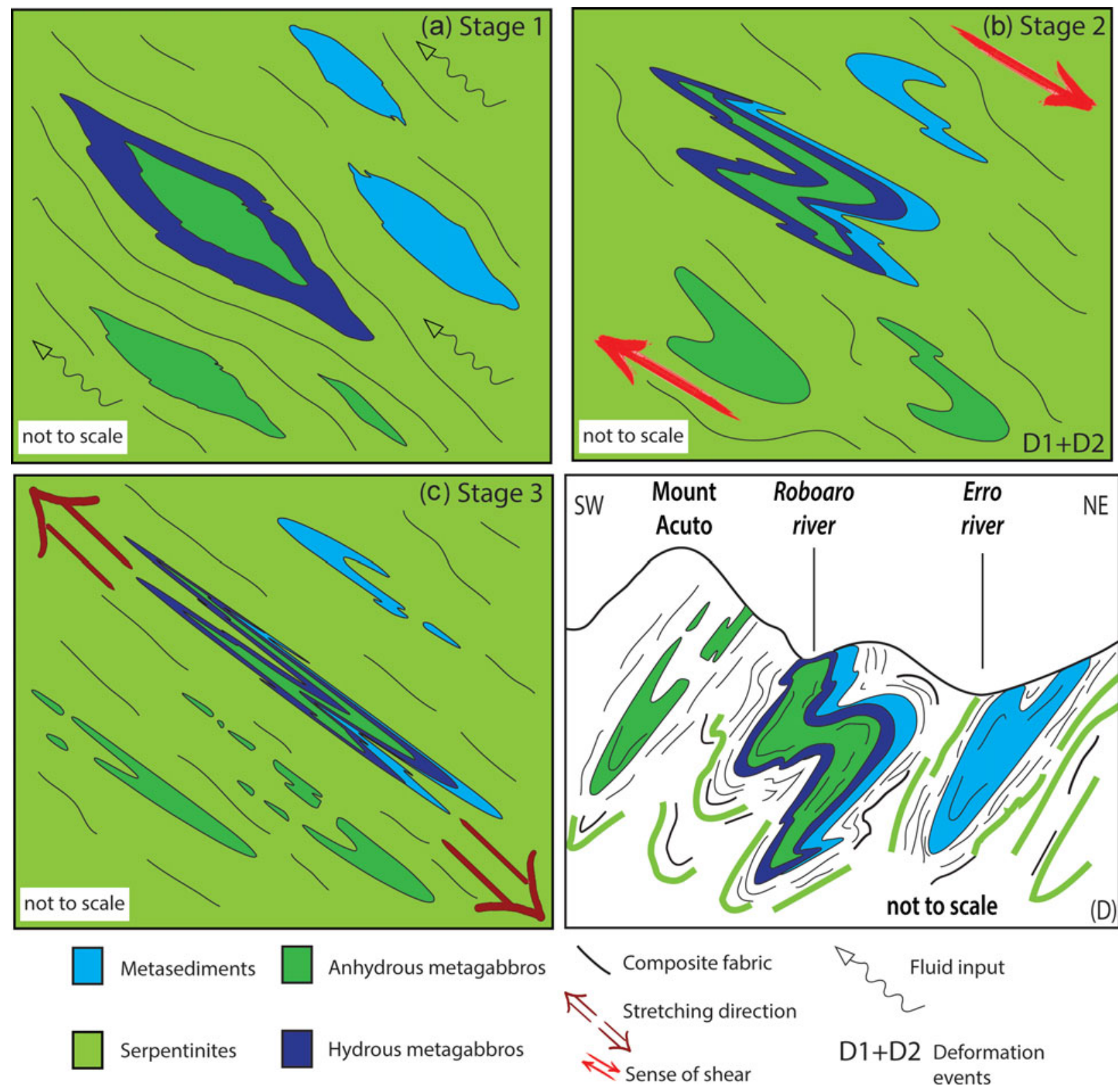

Figure 10. (Colour online) Schematic model of the progressive deformation of the study area. (a) Stage 1: metagabbro and metasediment lenses surrounded by serpentinites with circulating fluids. (b) Stage 2: Progressive deformational events linked with the metamorphic peak and exhumation stages that produced the alternating blue and green layering. (c) Stage 3: Later stretching of the metagabbro body that caused the boudinage of the green layer. (d) Interpretative schematic geological cross-section through the lawsonite-bearing metagabbro body.

characterized by $\mathrm{H}_{2} \mathrm{O}$ under-saturated conditions, with the occurrence of both lawsonite and epidote.

The low temperature recorded by the lawsonitebearing eclogitic metagabbro body led us to interpret this area as a portion of the top of the subducted slab coupled with the hydrated and 'cool' mantle wedge.

Both the multiple deformations recorded during the whole studied history of the body and the occurrence in the area of rocks with different paleogeographic origins (e.g. ocean versus continent), wrapped in a serpentinite matrix, witness that this sector was close to the slab-mantle interface that evolved in a shear regime. These rocks were merged within a low-viscosity serpentinite channel that brought them back to the surface.
Acknowledgements. We greatly appreciate the discussion with Laura Crispini, Laura Federico and Giovanni Capponi; we acknowledge Nicholas Vaiarini for the field assistance. We also thank Andrea Festa, Alicia López-Carmona and Idael Francisco Blanco-Quintero for their detailed and constructive comments which improved this manuscript. This work was financially supported by PRIN 2010 project 'Nascita e morte dei bacini oceanici: processi geodinamici dal rifting alla collisione continentale negli Orogeni mediterranei e circum-mediterranei', national Coordinator G. Capponi.

\section{Supplementary material}

To view supplementary material for this article, please visit https://doi.org/10.1017/S0016756817000395. 


\section{References}

Agard, P., Amato, P., Jolivet, L. \& Burov, E. 2009. Exhumation of oceanic blueschists and eclogites in subduction zones: timing and mechanisms. Earth-Science Reviews 92, 53-79.

Ague, J. J. \& Nicolescu, S. 2014. Carbon dioxide released from subduction zones by fluid-mediated reactions. Nature Geoscience 7, 355-60.

Altherr, R., Topuz, G., Marschall, H., Zack, T. \& LUDWING, T. 2004. Evolution of a tourmaline-bearing lawsonite eclogite from Elekdag area (Central Pontides, $\mathrm{N}$ Turkey): evidence for infiltration of slab-derived Brich fluids during exhumation. Contributions to Mineralogy and Petrology 148, 409-25.

Angiboust, S. \& AGARD, P. 2010. Initial water budget: the key to detaching large volumes of eclogitized oceanic crust along the subduction channel? Lithos 120, 45374.

Ballevre, M., Pitra, P. \& Bohn, M. 2003. Lawsonite growth in the epidote blueschists from the Ile de Groix (Armorican Massif, France): a potential geobarometer. Journal of Metamorphic Geology 21, 723-35.

Brouwer, F. M., Vissers, R. L. M. \& LAMB, W. M. 2002. Metamorphic history of eclogitic metagabbro blocks from a tectonic mélange in the Voltri Massif, Ligurian Alps, Italy. Ofioliti 27, 1-16.

Brun, J. P. \& FACCENNA, C. 2008. Exhumation of highpressure rocks driven by slab rollback. Earth and Planetary Science Letters 272, 1-7.

Cannaò, E., Scambelluri, M., Agostini, A., Tonarini, S. \& GoDARD, M. 2016. Linking serpentinite geochemistry with tectonic evolution at the subduction interface: the Voltri Massif case study (Ligurian Western Alps, Italy). Geochimica et Cosmochimica Acta 190, 115-33.

CAPPONI, G. 1987. Alcune considerazioni sul Massiccio di Voltri (Alpi Liguri). Bollettino della Società Geologica Italiana 106, 633-45.

CAPPONI, G. 1991. Megastructure of the south-eastern part of the Voltri Group (Ligurian Alps): a tentative interpretation. Bollettino della Società Geologica Italiana 110, 391-403.

CAPPONI, G. \& CRISPINI, L. 1997. Progressive shear deformation in the metasediments of the Voltri Group (Ligurian Alps, Italy): occurrence of structures recording extension parallel to the regional foliation. Bollettino della Società Geologica Italiana 116, 267-77.

CAPPONI, G. \& CRISPINI, L. 2002. Structural and metamorphic signature of alpine tectonics in the Voltri Massif (Ligurian Alps, northwestern Italy). Eclogae Geologicae Helvetiae 95, 31-42.

CApponi, G. \& Crispini, L. 2008a. Note Illustrative della Carta Geologica d'Italia alla scala 1: 50.000 Foglio 213 Genova. Firenze: SELCA.

CAPPONI, G. \& CRISPINI, L. 2008b. Carta Geologica d'Italia alla scala 1:50000, Foglio 213 - 230 "Genova". Apat - Regione Liguria. Firenze: SELCA.

Capponi, G., Gosso, G., Scambelluri, M., Siletto, G. \& TAllone, S. 1994. Carta Geologico - Strutturale del settore centro meridionale del Gruppo di Voltri (Alpi Liguri) e note illustrative. Bollettino della Società Geologica Italiana 113, 383-94.

Caron, J. M. \& PÉquignot, G. 1986. The transition between blueschist and lawsonite-bearing eclogites based on observations from Corsican metabasalts. Lithos 19, 20518.

Carswell, D. A. 1990. Eclogite Facies Rocks. Berlin: Springer.
Carswell, D. A., Tucker, R. D., O’Brien, P. J. \& Krogh, T. E. 2003. Coesite micro-inclusions and the $\mathrm{U} / \mathrm{Pb}$ age of zircons from the Hareidland eclogite in the Western Gneiss Region of Norway. Lithos 67, 181-90.

Çetinkaplan, M., Candan, O., Oberhänsli, R. \& BousQueT, R. 2008. Pressure-temperature evolution of lawsonite eclogite in Sivrihisar; Tavşanlı Zone-Turkey. Lithos 104, 12-32.

Chiesa, S., Cortesogno, L., Forcella, F., Galli, M., Messiga, B., Pasquare, G., Pedemonte, G. M., Piccardo, G. B. \& Rossi, P. M. 1975. Assetto strutturale ed interpretazione geodinamica del Gruppo di Voltri. Bollettino della Società Geologica Italiana 94, 555-82.

Compagnoni, R. \& Maffeo, B. 1973. Jadeite-bearing metagranites 1.s. and related rocks in the Mount Mucrone area (Sesia-Lanzo Zone, Western Italian Alps). Schweizerische Mineralogische und Petrographische Mitteilungen 53, 355-78.

Connolly, J. A. D. 1990. Multivariable phase diagrams: an algorithm based on generalized thermodynamics. American Journal of Science 290, 666-718.

Cortesogno, L. \& Forcella, F. 1978. Il Massiccio cristallino di Arenzano, frammento di crosta continentale Brianzonese al margine meridionale del Gruppo di Voltri. Rendiconti della Società Geologica Italiana 28, 225-7.

Cortesogno, L., Forcella, F., Lucchetti, G. \& Rossi, P.M. 1981. Paragenesi di alta pressione e bassa temperatura in un klippe di metaofiollti nel settore nordoccidentale del Massiccio di Voltri. Rendiconti Società Italiana di Mineralogia e Petrologia 37, 447-80.

Cortesogno, L., Galbiati, B. \& Principi, G. 1980. Le brecce serpentinitiche giurassiche della Liguria orientale. Archives des Sciences Genève 33, 185-200.

Cortesogno, L., Galbiati, B. \& Principi, G. 1981. Descrizione dettagliata di alcuni caratteristici affioramenti di brecce serpentinitiche della Liguria orientale ed interpretazione in chiave geodinamica. Ofioliti 6, 47-76.

Cortesogno, L., Lucchetti, G. \& Massa, B. 1981. Rocce oficarbonate e marmi a silicati nel Massiccio di Voltri: origine e significato, chimismo dei minerali ed equilibri paragenetici. Rendiconti Società Italiana di Mineralogia e Petrologia 37, 481-507.

Davis, P. B. \& Whitney, D. L. 2006. Petrogenesis of lawsonite and epidote eclogite and blueschist, Sivrihisar Massif, Turkey. Journal of Metamorphic Geology 24, 82349 .

Federico, L., Capponi, G., Crispini, L. \& Scambelluri, M. 2004. Exhumation of alpine high-pressure rocks: insights from petrology of eclogite clasts in the Tertiary Piedmontese basin (Ligurian Alps, Italy). Lithos 74, 21-40.

Federico, L., CAPponi, G., Crispini, L., Scambelluri, M. \& Villa, M. I. 2005. ${ }^{39} \mathrm{Ar} /{ }^{40} \mathrm{Ar}$ dating of high-pressure rocks from the Ligurian Alps: evidence for a continuous subduction-exhumation cycle. Earth and Planetary Science Letters 240, 668-80.

Federico, L., Crispini, L., Scambelluri, M. \& Capponi, G. 2007a. Ophiolite mélange zone records exhumation in a fossil subduction channel. Geology 35, 499-502.

Federico, L., Crispini, L., Scambelluri, M. \& Capponi, G. 2007b. Different PT paths recorded in a tectonic mélange (Voltri Massif, NW Italy): implications for the exhumation of HP rocks. Geodinamica Acta 20, $3-19$. 
ForNeris, J. F. \& HollowaY, J. R. 2004. Evolution of mineral compositions during eclogitization of subducting basaltic crust. American Mineralogist 89, 1516-24.

Ghent, E. D., Stout, M. Z. \& Erdmer, P. 1993. Pressuretemperature evolution of lawsonite-bearing eclogites, Pinchi Lake, British Columbia. Journal of Metamorphic Geology 11, 279-90.

Ghent, E. D., Tinkhan, D. \& Marr, R. 2009. Lawsonite eclogites from the Pinchi Lake area, British Columbia new P-T estimates and interpretation. Lithos 109, 248 53.

Groppo, C., Rolfo, F., Sachan, H. K. \& Rai, S. K. 2016. Petrology of blueschist from the Western Himalaya (Ladakh, NW India): exploring the complex behavior of a lawsonite-bearing system in a paleo-accretionary setting. Lithos 252, 41-56.

Hansen, L. D., Dipple, G. M., Gordon, T. M. \& Kellet, D. W. A. 2005. Carbonated serpentinite (listwanite) at Atlin, British Columbia: a geological analogue to carbon dioxide sequestration. The Canadian Mineralogist 43, 225-39.

Harlow, G. E., Hemming, S. R., Lallemant, H. G., Sisson, V. B. \& SoresEN, S. S. 2004. Two highpressure low-temperature serpentinite-matrix melange belts, Motagua Fault zone, Guatemala: a record of Aptian and Maastrichtian collisions. Geology 32, 17-20.

Holland, T., BaKer, J. \& Powell, R. 1998. Mixing properties and activity-composition relationships of chlorites in the system $\mathrm{MgO}-\mathrm{FeO}-\mathrm{Al}_{2} \mathrm{O}_{3}-\mathrm{SiO}_{2}-\mathrm{H}_{2} \mathrm{O}$. European Journal of Mineralogy 10, 395-406.

Holland, T. \& Powell, R. 1996. Thermodynamics of order-disorder in minerals. Symmetric formalism applied to solid solutions. American Mineralogist 81, 1425-37.

Holland, T. \& Powell, R. 1998. An internally consistent thermodynamic data set for phases of petrological interest. Journal of Metamorphic Geology 16, 309-43.

Kelemen, P. B. \& MANNing, C. E. 2015. Reevaluating carbon fluxes in subduction zones, what goes down, mostly comes up. PNAS 112, E3997-E4006.

Kerrick, D. M. \& ConNolly, J. A. D. 1998. Subduction of ophicarbonates and recycling of $\mathrm{CO}_{2}$ and $\mathrm{H}_{2} \mathrm{O}$. Geology 26, 375-8.

KRETZ, R. 1983. Symbols for rock-forming minerals. American Mineralogist 68, 277-9.

Krogh, E. J. 1982. Metamorphic evolution of Norwegian country-rock eclogites, as deduced from mineral inclusions and compositional zoning in garnets. Lithos 15, 305-21.

Hawthorne, F. C., Oberti, R., Harlow, G. E., Maresch, W. V., Martin, R. F., Schumacher, J. C. \& Welch, M. D. 2012. IMA Report. Nomenclature of the amphibole supergroup. American Mineralogist 97, 203148.

Lardeaux, J.-M., Caron, J.-M., Nisio, P., Péquignot, G. \& BOUdEUlLe, M. 1986. Microstructural criteria for reliable thermometry in low-temperature eclogites. Lithos 19, 187-203.

Liou, J. G., Zhang, R., Ernst, W. G., Liu, J. \& McLimans, R. 1998. Mineral parageneses in the Piampaludo eclogitic body, Gruppo di Voltri, Western Ligurian Alps. Schweizerische Mineralogische und Petrographische Mitteilungen 78, 317-35.

López-Carmona, A., Abati, J., Pitra, P. \& Lee, J. K. W. 2014. Retrogressed lawsonite blueschists from the NW Iberian Massif: P-T-t constraints from thermodynamic modelling and ${ }^{40} \mathrm{Ar} /{ }^{39} \mathrm{Ar}$ geochronology. Contributions to Mineralogy and Petrology 167, 987.
López-Carmona, A., Kusky, T. M., Santhos, M. \& Abati, J. 2011. P-T and structural constraints of lawsonite and epidote blueschists from Liberty Creek and Seldovia: tectonic implications for early stages of subduction along the southern Alaska convergent margin. Lithos 121, 100-16.

López-Carmona, A., Pitra, P. \& Abati, J. 2013. Blueschistfacies metapelites from the Malpica-Tui Unit (NW Iberian Massif): phase equilibria modelling and $\mathrm{H}_{2} \mathrm{O}$ and $\mathrm{Fe}_{2} \mathrm{O}_{3}$ influence in high-pressure assemblages. Journal of Metamorphic Geology 31, 263-80.

Malatesta, C., Crispini, L., Federico, L., Capponi, G. \& SCAMBELluRI, M. 2012a. The exhumation of high pressure ophiolites (Voltri Massif, Western Alps): insights from structural and petrologic data on meta-gabbro bodies. Tectonophysics 568/569, 102-23.

Malatesta, C., Gerya, T., Scambelluri, M., Federico, L., CRISPINI, L. \& CAPPONI, G. 2012b. Intraoceanic subduction of "heterogeneous" oceanic lithosphere in narrow basins: 2D numerical modeling. Lithos 140-141, 234-51.

Maruyama, S., Isozaki, Y., Kimura, G. \& Terabayashi, M. 1997. Paleogeographic maps of the Japanese Islands: plate tectonic synthesis from $750 \mathrm{Ma}$ to the present. $I_{S}$ land Arc 6, 121-42.

Mattinson, C. G., Zhang, R. Y., Tsujimori, T. \& Liou, J. G. 2004. Epidote-rich talc-kyanite-phengite eclogites, Sulu terrane, eastern China: P-T-f $(\mathrm{O} 2)$ estimates and the significance of the epidote-talc assemblage in eclogite. American Mineralogist 89, 1772-83.

McBirney, A., Aoki, K. I. \& BAss, M. N. 1967. Eclogites and jadeite from Motagua Fault Zone Guatemala. American Mineralogist 52, 908-18.

Morimoto, N., Fabries, J., Ferguson, A. K., Ginzburg, I. V., Ross, M., Seifert, F. A., Zussman, J., Aoki, K. \& GotTARDI, G. 1988. Nomenclature of pyroxenes. American Mineralogist 73, 1123-33.

Och, D. J., Leitch, E. C., Caprarelli, G. \& Watanabe, T. 2003. Blueschist and eclogite in a tectonic melange, Port Macquarie, New South Wales, Australia. Mineralogical Magazine 67, 609-24.

Oh, C. W., Liou, J. G. \& Maruyama, S. 1991. Lowtemperature eclogites and eclogitic schist in Mn-rich metabasites in Ward Creek, California - $\mathrm{Mn}$ and $\mathrm{Fe}$ effects on transition between blueschist and eclogite. Journal of Petrology 32, 275-302.

Oкамото, K. \& Maruyama, S. 1999. The high-pressure synthesis of lawsonite in the MORB $+\mathrm{H}_{2} \mathrm{O}$ system. American Mineralogist 84, 362-73.

Parkinson, C. D., Miyazaki, K., Wakita, K., Barber, A. J. \& CARswell, D. A. 1998. An overview and tectonic synthesis of the pre-Tertiary very-high pressure metamorphic and associated rocks of Java, Sulawesi and Kalimantan, Indonesia. Island Arc 7, 184-200.

Poli, S. \& Schmidt, M. W. 1995. $\mathrm{H}_{2} \mathrm{O}$ transport and release in subduction zones: experimental constraints on basaltic and andesitic systems. Journal of Geophysical Research: Solid Earth 100, 22299-314.

Poli, S. \& SchmidT, M. W. 1997. The high-pressure stability of hydrous phases in orogenic belts: an experimental approach on eclogite-forming processes. Tectonophysics 273, 169-84.

Ramsay, J. G. \& Huber, M. I. 1987. The Techniques of Modern Structural Geology. Vol. 2: Folds and Fractures. London: Academic Press, 700 pp.

Ravna, E. J. K., Andersen, T. B., Jolivet, L. \& De CaPITANI, C. 2010. Cold subduction and the formation of lawsonite eclogite - constraints from prograde 
evolution of eclogitized pillow lava from Corsica. Journal of Metamorphic Geology 28, 381-5.

Rubatto, D. \& Scambelluri, M. 2003. U-Pb dating of magmatic zircon and metamorphic baddeleyite in the Ligurian eclogites (Voltri Massif, Western Alps). Contributions to Mineralogy and Petrology 146, 341-55.

Scambelluri, M., Bebout, G. E., Belmonte, D., Gilio, M., Campomenosi, N., Collins, N. \& CRispini, L. 2016. Carbonation of subduction-zone serpentinite (highpressure ophicarbonate; Ligurian Western Alps) and implications for the deep carbon cycling. Earth and Planetary Science Letters 441, 155-66.

Scambelluri, M., Hoogerduijn Strating, E. H., Piccardo, G. B., Vissers, R. L. M. \& Rampone, E. 1991. Alpine olivine and titanian clinohumite bearing assemblages in the Erro-Tobbio peridotites. Journal of Metamorphic Geology 9, 79-91.

Schmidt, M. W. \& Poli, S. 1998. Experimentally based water budgets for dehydrating slabs and consequences for arc magma generation. Earth and Planetary Science Letters 163, 361-79.

Shibakusa, H. \& Maekawa, H. 1997. Lawsonite-bearing eclogitic metabasites in Cazadero area, northern California. Mineralogy and Petrology 61, 163-80.

SPANDleR, C. \& Pirard, C. 2013. Element recycling from subducting slabs to arc crust: a review. Lithos 170-171, 208-23.

TsujIMORI, T. \& ERnst, W. G. 2014. Lawsonite blueschists and lawsonite eclogites as proxies for palaeosubduction zone processes: a review. Journal of Metamorphic Geology 32, 437-54.

Tsujimori, T., Liou, J. G. \& Coleman, R. G. 2005. Coexisting retrograde jadeite and omphacite in a jadeitebearing lawsonite eclogite from the Motagua Fault Zone, Guatemala. American Mineralogist 90, 836-42.

Tsujimori, T., Sisson, V. B., Liou, J. G., Harlow, G. E. \& SORENSEN, S. S. 2006a. Very-low-temperature record of the subduction process: a review of worldwide lawsonite eclogites. Lithos 92, 609-24.

Tsujimori, T., Sisson, V. B., Liou, J. G., Harlow, G. E. \& SoRENSEN, S. S. 2006b. Petrologic characterization of Guatemalan lawsonite eclogite: eclogitization of subducted oceanic crust in a cold subduction zone. In Ultrahigh-Pressure Metamorphism: Deep Continental Subduction (eds B. H. Hacker, W. C. McClelland \& J. G. Liou), pp. 147-68. Geological Society of America Special Papers no. 403.

Usui, T., Nakamura, E. \& Helmstaed, H. 2006. Petrology and geochemistry of eclogite xenoliths from the Colorado Plateau: implications for the evolution of subducted oceanic crust. Journal of Petrology 47, 929-64.

Usui, T., Nakamura, E., Kobayashi, K. \& Maruyama, S. 2003. Fate of the subducted Farallon plate inferred from eclogite xenoliths in the Colorado Plateau. Geology 31, 589-92.
VIDAL, O. \& PARRA, T. 2000. Exhumation paths of highpressure metapelites obtained from local equilibria for chlorite-phengite assemblages. Geological Journal 35, 139-61.

Vignaroli, G., Rossetti, F., Bouybaouene, M., Massonne, H. J., Theye, T., Faccenna, C. \& Funiciello, R. 2005. A counter-clockwise P$\mathrm{T}$ path for the Voltri Massif eclogites (Ligurian Alps, Italy). Journal of Metamorphic Geology 23, 533-55.

Vitale Brovarone, A. \& Beyssac, O. 2014. Lawsonite metasomatism: a new route for water to the deep Earth. Earth and Planetary Science Letters 393, 275-84.

Vitale Brovarone, A., Groppo, C., Hetényi, G., Compagnoni, R. \& Malavieille, J. 2011. Coexistence of lawsonite-bearing eclogite and blueschist: phase equilibria modelling of Alpine Corsica metabasalts and petrological evolution of subducting slabs. Journal of Metamorphic Geology 29, 583-600.

Watson, K. D. \& Morton, D. M. 1969. Eclogite inclusions in kimberlite pipes at Garnet Ridge, northeastern Arizona. American Mineralogist 54, 267-85.

Wei, C. J. \& Powell, R. 2003. Phase relations in highpressure metapelites in the system KFMASH $\left(\mathrm{K}_{2} \mathrm{O}\right.$ $\mathrm{FeO}-\mathrm{MgO}-\mathrm{Al}_{2} \mathrm{O}_{3}-\mathrm{SiO}_{2}-\mathrm{H}_{2} \mathrm{O}$ ) with application to natural rocks. Contributions to Mineralogy and Petrology 145, 301-15.

White, R. W., Powell, R. \& Phillips, G. N. 2003. A mineral equilibria study of the hydrothermal alteration in mafic greenschist facies rocks at Kalgoorlie, Western Australia. Journal of Metamorphic Geology 21, 45568.

Whitney, D. L. \& Evans, B. W. 2010. Abbreviations for names of rock-forming minerals. American Mineralogist 95, 185-7.

Zack, T., Rivers, T., Brumm, R. \& Kronz, A. 2004. Cold subduction of oceanic crust: implications from a lawsonite eclogite from the Dominican Republic. European Journal of Mineralogy 16, 909-16.

Zhang, J. X. \& Meng, F. C. 2006. Lawsonite-bearing eclogites in the north Qilian and north Altyn Tagh: evidence for cold subduction of oceanic crust. Chinese Science Bulletin 51, 1238-44.

Zhang, J. X., Meng, F. C. \& Wan, Y. S. 2007. A cold Early Paleozoic subduction zone in the North Qilian Mountains, NW China: petrological and U-Pb geochronological constraints. Journal of Metamorphic Geology 25, 285-304.

Zucali, M. \& Spalla, M. I. 2011. Prograde lawsonite during the flow of continental crust in the Alpine subduction: strain vs. metamorphism partitioning, a field-analysis approach to infer tectonometamorphic evolutions (Sesia-Lanzo Zone, Western Italian Alps). Journal of Structural Geology 33, 381-98. 